\title{
AFTER THE $12^{\mathrm{TH}}$ CENTURY: \\ WAR AND LEGAL ORDER \\ (OR, OF HISTORIOGRAPHY AND ITS CHIMERAS)
}

\author{
Federico Devís \\ UniversidAd DE CÁdIZ \\ SPAIN
}

Date of receipt: $9^{\text {th }}$ of October, 2013

Final date of acceptance: $10^{\text {th }}$ of September, 2014

\begin{abstract}
The publication in 2009 of John Watts's The Making of Polities renewed interest not only in the causal relation that is habitually taken for granted nowadays between war and the development of state institutions in the late medieval centuries (a question about which recent English historiography has produced other works of enormous interest), but also in the appropriateness of state categories to think about the changes that, driven by war or not, took place then in the field of the forms of political organisation of Western Europe. This paper looks at the the historiographic origins and development of the state-centred model of explaining those changes, and then explores (especially as regards the evolution of the idea of war itself) the potential for a jurisdictionalist model which, through a more contextualized reading of sources and closer attention to its long-term deployment since the $12^{\text {th }}$ century, has been reconstructing the recent legal and related historiographies from, especially, southern European countries. ${ }^{1}$
\end{abstract}

KeYWORDS

Modern State, Modern Historiography, Ius Commune, Constitutional History, War, Feud.

Capitalia Verba

Status Modernus, Historigraphia Moderna, Ius Commune, Historia Constitucionalis, Bellum, Feodum. 
Genly Ai stated: “Though I had been nearly two years on Winter I was still far from being able to see the people of the planet through their own eyes. I tried to, but my efforts took the form of self-consciously seeing a Gethenian first as a man, then as a woman, forcing him into those categories so irrelevant to his nature and so essential to my own". ${ }^{2}$

"The importance of concepts derives from their relationship to action." ${ }^{3}$

\section{State dynamic or translation problem?}

War is rompimiento de Reynos, o Principes, o comunidades, as Sebastián de Covarrubias described it in the early $17^{\text {th }}$ century, to which he also added -and he must have known being both a renowned lexicographer and chaplain to such a belligerent king as Phillip II- that conversely we use the term guerrilla, quando entre particulares ay pendencia, y enemistad formada, que acuden unos a una parte, y otros a otra, pero estas castigan los Principes de las republicas severamente. ${ }^{4}$ Nowadays anyone finding both definitions together would perhaps find no reason not to suppose, being carried away by a false sense of familiarity with "Siglo de Oro" Spanish, that particulares in the second definition could refer to nothing other than persons or individuals who, as such, act in the private context and whose resort to arms to settle their differences was obviously punished by those who embodied public authority, the only ones to whom the legitimate use of armed force corresponds. Perhaps that reading might even equate those concepts not with kingdoms, communities or republics but (aiming to make them easier to understand by a modern mind) States, since (whether singular or plural) this is the term that today most commonly evokes

\footnotetext{
1. This study is part of the research project HAR-2009-13225 financed by the Ministry of Science and Innovation of the Government of Spain. A draft version of the text was discussed in the meeting about Desenvolupaments bèl-lics al segle XII held in the Rovira i Virgili University in September 2012. My thanks to María Bonet Donato, Pere Benito Monclús, Carlos Estepa Díez, Amancio Isla Frez, Carlos Laliena Corbera and Pascual Martínez Sopena, who attended the above-mentioned meeting, for their pertinent observations on what I presented there. Ramón Vargas-Machuca Ortega and José Luis Rodríguez Sández, as well as two anonymous evaluators, also deserve my gratitude for the valuable suggestions they made after a careful reading of the full text, so that all errors and deficiencies in this final version can only be imputed to the contumacy or negligence of the author. Thanks go to Rafael Galán Moya for revising the translation into English.

2. Le Guin, Ursulak. The Left Hand of Darkness. New York: Ace Books, 1969: chapter 1.

3. Richter, Melvin. "Introduction: Translation, the History of Concepts and the History of Political Thought", Why Concepts Matter: Translating Social and Political Thought, Martin, J. Burke, Melvin Richter, eds. Leiden-Boston: Brill, 2012: 9.

4. "breaking of Kingdoms, or Princes, or communities", "when there are disputes between individuals, and enmity formed, they all turn to one side, and other on another, but these punish the Princes of the republics severely". Covarrubias, Sebastián de. Tesoro de la lengua castellana, o española. Madrid: Luis Sánchez impresor, 1611: 455r. <http://fondosdigitales.us.es/fondos/libros/765/16/tesoro-de-la-lenguacastellana-o-espanola/>.
} 
the idea of public authority, the territory it is projected onto, and the matters that are specific to it. Also around 1600, war, the rompimiento or rift that it should only be appropriate to call so, would finally become a question of and between States. At least in this respect, the past does not seem to be, as has been oft repeated lately, a foreign country. ${ }^{5}$

In identical circumstances, a professional historian would undoubtedly exercise greater prudence when choosing concepts. Consider one of the most recent volumes published in one of the leading collections for academic history, the French "Nouvelle Clio", a work dedicated to the century which covered most of the life of the author of the Tesoro and that furthermore pays very special attention to the Hispanic Monarchy. ${ }^{6}$ Assuredly, States also appear here, right from the title of the work, as subjects and actors in a scenario which seems to be of "international relations", in whose development in the $16^{\text {th }}$ century armed conflicts played a very notable part, to the point that war was precisely, as the book stated, il piu formidabile vettore della crescita dello Stato moderno. ${ }^{7}$ However, opting for these concepts means the author feels obliged to start by offering some explanations, aware that they are not as evident and unequivocal as they may seem. On one hand, he states that talking about "international relations" could justifiably be anachronistic, as in the $16^{\text {th }}$ century il termine 'nazione' non ha il senso che acquisirà a partire dal XVIII secolo, ${ }^{8}$ to which he adds that it should be borne in mind that, although its weight grew as the century went by, then lo Stato non ha il monopolio delle relazioni diplomatiche. ${ }^{9}$ On the other hand, regarding the reality that one wishes to imply with the word State, always written with a capital letter, the difficulties this generates are revealed by the fact that the identical epigraph used to title two chapters of the book, one devoted to the techniques of government and the other to political ideas and practices, does little more than revive an old question formulated by Federico Chabod over fifty years ago: "Is there a State in the Renaissance?" The interrogative form was also used in the epigraph heading one of the sections of the bibliography of the volume: "Genesis of the modern State?". Indeed the author thinks that la riflessione sullo Stato del Rinascimento sembra essere giunta a una forma di aporia storiografica ${ }^{10}$ and, in any case, it should not remain in the paradigm suggested by the last epigraph cited, which has been the key to the dominant reading in recent decades while also the

5. A topic about which an essential reflection is Chittolini, Giorgio. "Un paese lontano". Società e storia, 26 (2003): 331-354.

6. Tallon, Alain. L'Europe au XVIe siècle: États et relations internationales. Paris: Presses Universitaires de France, 2010. I use here the Italian translation: Tallon, Alain. L'Europa del Cinquecento: Stati e relazioni internazionali. Rome: Carocci, 2013.

7. "the most formidable vector for the development of the modern State". Tallon, Alain. L'Europa del Cinquecento...: 157.

8. "the term 'nation' did not have the sense it would acquire from the 18th century". Tallon, Alain. L'Europa del Cinquecento...: 17.

9. "the State does not have the monopoly on diplomatic relations". Tallon, Alain. L'Europa del Cinquecento...: 16 .

10. "the reflection about the State of the Renaissance seems to have reached a kind of historiographic impasse". Tallon, Alain. L'Europa del Cinquecento...: 209. 
subject of intense debates. The author explains why he, in the end, favours a Statecentred explanation:

Da questi dibattiti, a volte assai vivace, sulle nozioni di Stato e di nazione / si può tuttavia desumere che il XVI secolo vede una affermazione senza precedenti del potere statale, uno 'Stato-patrimonio' più che uno Stato-nazione, senza che questa concezione nazionale sia assente $o$ in contraddizione con la prima. ${ }^{11}$

However, given such a detour and the necessity for adjectives to qualify the State that really existed in that time, it does not seem misplaced or meaningless to ask if the problem is not more in the substantive.

The problem, if you like, is one of translation, as suggested above, an operation as necessary as it is delicate; of translation, understood here, from the language of the sources to the language of the historian, which although they can be same language can also correspond to different phases of its evolution, which inevitably places a filter between the two - a cultural filter between two different contexts- which should not be ignored. In the introduction to La société féodale, Marc Bloch stated that "las palabras son como monedas muy usadas: a fuerza de circular de mano en mano, pierden su relieve etimológico". ${ }^{12}$ Some years earlier, Lucien Febvre, with his habitual belligerent eloquence, reproached Julien Benda for appealing to a supposedly timeless, "metaphysical" idea of nation in using this word in his Esquisse d'une histoire des Français dans leur volonté d'être une nation:

Lo que usted ha hecho es solamente reforzar la tendencia a tomar las palabras más claras hoy para los hombres de hoy como confortables y seguros vehículos con que remontar el curso de los siglos, sin necesidad de cambiar nunca de sitio o de medio de transporte. ${ }^{13}$

Despite such warnings, issued in the interwar period by two such enormously influential figures in the later development of the historical discipline during the $20^{\text {th }}$ century, it seems that it was not until more recently that historians have begun to take seriously and discuss in depth the problems derived from their condition as "translators". ${ }^{14}$ Conversely, for a long time and in general, they have rather tended

11. "From these debates, sometimes very lively, around the notions of State and nation, one can nevertheless derive that the 16th century saw an unprecedented affirmation of state power, a 'patrimonial State' more than a nation-State, without this national conception being absent or in contradiction with the former". Tallon, Alain. L'Europa del Cinquecento...: 17.

12. "words, like well-worn coins, in the course of constant circulation lose their clear outline". I cite the version in Bloch, Marc. La sociedad feudal. Mexico: Unión Tipográfica Editorial Hispano Americana, 1979: I, 2-3.

13. "What you have done is only reinforce the tendency to take the clearest words for today's men as comfortable and safe vehicles with which to go back through the centuries, without the need ever to change place or means of transport." Febvre, Lucien. Combates por la historia. Barcelona: Ariel, $1970: 129$. 14. Adams, William Paul. "The Historian as Translator: An Introduction". The Journal of American History, 85/4 (1999): 1283-1289; Ghosh, Peter. "Translation as a Conceptual Act". Max Weber Studies, 2/1 (2001): 59-63; and above all now Why Concepts Matter cit., especially on this point the contribution by Palonen, 
to avoid such a condition, or at least to conduct themselves, with more or less awareness, first as enthusiastic followers of Jorge Luis Borges in his defence of the translator's "creative infidelity" than as firm supporters in this matter (which seems more de rigueur among those who aim to study the changes in societies over time) of Octavio Paz's attitude, who, a defender of fidelity to and respect for the source text to safeguard its differences, saw in this the way that the translator se obliga a reconocer que el mundo no termina en nosotros y que el hombre es los hombres. ${ }^{15}$

To return to the question that concerns us here: for the entire "long Middle Ages" that Jacques Le Goff speaks of, or alternatively the longs temps modernes that others favour $^{16}$ (although it is a more equivocal expression), that is, the period of Western history between the $12^{\text {th }}$ and $18^{\text {th }}$ centuries, it can be said what is nowadays less disputed about the chronology traditionally labelled Middle Ages: namely, that there is then no equivalent of the term State in its current political definition (that is to say, no sooner than its meaning as a specific, and therefore historical, form of political organization is taken seriously). The word state does exist, but none of its meanings corresponds with this definition, as can be easily checked with a contextualised reading of the entry in the Covarrubias's lexicon we started with. ${ }^{17}$ And there is also a political vocabulary specific to that age, none of whose terms is a direct equivalent, as we argued. Therefore, translating this vocabulary when the occasion arises by resorting to the state categories amounts to resorting to what is usually called, in grammar, a false friend, as well as ignoring that (as Reinhart Koselleck has insisted over the recent decades) all translation involves a reconceptualization; in the German historian's words: Toda traducción al propio presente implica una historia conceptual. ${ }^{18}$

Thus, to talk about the difficulties that affected the process of "State Building" in the $12^{\text {th }}$ century in the Christian principalities in the Near East, or considering in the same way, or even as "state-rebuilding", the progress of the CastilianLeonese Reconquest around the same time, to cite two recent examples, ${ }^{19}$ is at least imprecise and equally leads to confusion. However, let us move on and

Kari. "Reinhart Koselleck on Translation, Anachronism and Conceptual Change", Why concepts matter: translating social and political thought, Martin J. Burke, Melvin Richte, eds. Leiden-Boston: Brill, 2012 : 73-92.

15. "is forced to recognize that the world does not end in us and that man is men". See Sáenz, Miguel. Servidumbre y grandeza de la traducción. Madrid: Real Academia Española, 2013, which is the author's speech on entering this institution and where I take the quotes from.

16. Tallon, Alain. L'Europa del Cinquecento...: 15.

17. A relevant comment can be found in Clavero, Bartolomé. Razón de estado, razón de individuo, razón de historia. Madrid: Centro de Estudios Constitucionales, 1991: 16-21.

18. "All translation into the present implies a conceptual history". Koselleck, Reinhart. Historias de conceptos: estudios sobre semántica y pragmática del lenguaje político y social. Madrid: Trotta, 2012: 10. However, the original text the quote is taken from dates from 1986.

19. Barber, Malcolm. "The Challenge of State Building in the Twelfth Century: the Crusader States in Palestine and Syria". Reading Medieval Studies, 36 (2010): 7-22; Purkis, William J. "Eleventh-and TwelfthCentury Perspectives of State Building in the Iberian Peninsula". Reading Medieval Studies, 36 (2010): 57 75. This is a monographic issue of the journal dedicated to "Crusading and State Building in the Central Middle Ages". 
place ourselves in the last centuries conventionally still regarded as medieval, in relation with which the focus of State-building appears more elaborate and is most commonly accepted. Let us do so, however, from a perspective of continuity regarding the immediately preceding centuries, that is, without the " $14^{\text {th }}$-century crisis" intervening and making us lose sight of the developments in matters of political organisation that had taken place before the "crisis", in the $12^{\text {th }}$ and $13^{\text {th }}$ centuries, during the period of European expansion and deployment. This is precisely the perspective that John Watts adopts in his important recent efforts to rescue the late Medieval centuries, as far as their political history is concerned, from their habitual consideration as centuries of transition or transformation between the "medieval" and the "early modern", that is, of their ambiguous or ambivalent treatment around ideas of exhaustion and conclusion on one hand, and genesis and delivery, on the other. ${ }^{20}$ And it is precisely from that standpoint that Watts forestalls the emphasis on the part played by war in the usual narrative and image that traditional and less traditional historians construct of the 14th and 15th centuries. The former group of historians draw on war as another factor whose frequency and ubiquity, together with other well-known calamities, contributed decisively to giving the late Middle Ages, or at least part of this, a rather sombre character. The second group, those historians less attached to the renowned -and soon centennial- "autumn" metaphor, who form a majority nowadays, invoke war as the "midwife" (in Watts' own expression) of the modern State - that is to say, as the major cause (actually an independent explanatory variable in many cases) in the unfolding of a new taxation (a State taxation, it is claimed) that would be at the basis of a new institutional reality, the modern State, whose origin or genesis thus becomes the overarching element of the political history of the late Middle Ages.

However, Watts thinks that this stereotypical view of the Late Middle Ages as an age of greater armed conflictivity is not justified. Neither the size of armies deployed, nor its duration and intensity or destructive capacity made war undergo any significant change compared with the earlier period, at least prior to the outbreak of the Italian Wars of the middle of the last decade of the $15^{\text {th }}$ century. ${ }^{21}$

20. Watts, John. The Making of Polities: Europe 1300-1500. Cambridge (UK): Cambridge University Press, 2009. What is said below only aims to echo Watts' approach. For a more detailed analysis, see Challet, Vincent. "John Watts, The Making of Polities (Europe, 1300-1500)". Cahiers de recherches médiévales et humanistes. (2009) [5 september 2010]. Garnier Éditions Classiques. 8 september 2013. <http://crm. revues.org/12070>; Lazzarini, Isabella. "Il sistema politico europeo alla fine del medioevo. A proposito di un libro di John Watts". Storica, 48 (2010): 121-134.

21. This date also serves as a turning point in the periodisation used by Black, Jeremy. War: A Short History. London \& New York: Continuum, 2009. Contrary to the idea of the existence of a "military revolution" in early modern Europe and in favour of placing the emphasis in the military history of the continent more on the elements of continuity and a slow and gradual evolution between the medieval and early modern periods, while rejecting the simplicity which has sometimes been seen in the development and characterístics of warfare in the Middle Ages, Black states that "it is unclear that early-modern warfare was more brutal, in Europe or elsewhere, than its medieval predecessor" (Black, Jeremy. War: A Short History...: 71). On the other hand, John France, another leading specialist in military history, concluded that between 1300 and 1650 "much progress had been made in adapting to the 
It would have been an exaggerated and undue generalisation of the experience of the kingdom of France, the main scenario of the Hundred Years War, and the greater abundance and descriptive wealth of the sources that led to this error of appreciation.

Although they were not more frequent or very different from those of the immediately previous centuries, it is obvious that there were wars in the Late Middle Ages. However, Watts does not believe these should be considered "the great motor of later medieval political life". ${ }^{22}$ These wars were the cause but also the effect and consequence of the changes that were then occurring in the forms of organisation and modes of political action, which were thus not only the result of the pressure exerted by war, but also factors in their outbreak. Was it "War made the state, and the state made war" as Charles Tilly summarised from historical sociology in a famous formula in the mid 1970s? ${ }^{23}$ This was not exactly so, as in Watts' opinion, the adoption of a state perspective distorts the nature of those changes, initiated in the $12^{\text {th }}$ and $13^{\text {th }}$ centuries and to understand which the notion of State is nowadays of little use, and is even an encumbrance. This is because, among other reasons, even when it were possible to recognise practices of power identifiable as statist, these were far from being either the only ones or the norm, and placing emphasis on these hinders recognition of "the interaction of a multiplicity of valid and effective power forms and power types" typical of the period. ${ }^{24}$ And, on the other hand, because the interpretative framework of State growth contributes "surprisingly little", in fact, to explain the course of political events in the $14^{\text {th }}$ and $15^{\text {th }}$ centuries. $^{25}$

new gunpowder technology, but European armies remained incoherent, ill-organised and ill-disciplined" (France, John. Perilous Glory: The Rise of Western Military Power. New Haven \& London: Yale University Press, 2011: 163). A decade earlier, the same historian had noted the imbalance between the enormous attraction that the military history of the last two centuries of the Middle Ages exerted and the much lesser interest generated by the rest of the period: France, John, "Recent Writing on Medieval Warfare: From the Fall of Rome to c. 1300". The Journal of Military History, 65/2 (2001): 441-473. For a wideranging discussion about continuity and change in European military history between the $14^{\text {th }}$ and $18^{\text {th }}$ centuries, see European Warfare, 1350-1750, ed. Frank Tallet, David J.B. Trim. Cambridge (UK): Cambridge University Press, 2010.

22. Watts, John. The Making of Polities...: 25.

23. Tilly, Charles. "Reflections on the History of European State-Making", The Formation of National States in Western Europe, Charles Tilly ed. Princeton: Princeton University Press, 1975: 42. For a recent attempt to update and validate Tilly's theses, associating them with the idea of a series of military revolutions, see Fortmann, Michel. Les Cycles de Mars: révolutions militaires et édification étatique de la Renaissance a nos jours. Paris: Economica, 2010. See also Morillo, Stephen; Michael F. Pavkovic. What Is Military History? Cambridge: Polity Press, 2013: 77 and following, on the controversies over the very idea of "military revolution", which bring into relief the relevance of said idea to military history's rehabilitation as a discipline during the second half of the 20th century (a relevance that seems much less justified in light of its questionable intrinsic consistency and explanatory power).

24. Watts, John. The Making of Polities...: 32-33.

25. Watts, John. The Making of Polities...: 33. 


\section{Historiography}

Naturally, the state or statist focus is far from being recent. After all, history as an academic discipline arose in the $19^{\text {th }}$ century hand in hand with, and in the service to, the State, above all as an exercise in the latter's legitimation. The original professional historian was a civil servant, an employee charged with a public function that was understood as being exclusive to the State. And in the wake of a statist culture -in which we have been also educated and socialised as citizens since then-, successive generations of historians have grown accustomed to thinking of politics, or the political, in relation with, if not as synonyms of, the State. Identifying the acts or organisational forms characteristic of a given field of action or social experience which the historian isolates and labels as the sphere of politics; identifying thus all of that as "natural", and all legitimate political power with what is proper of the State, somehow constitutes "historiographic commonsense". ${ }^{26}$

The approach that links war, taxation and the configuration of the State is not really an invention of recent decades. In the first decade of the $20^{\text {th }}$ century, Otto Hintze, one of the fathers of modern comparative constitutional history, explicitly indicated the importance of mutual relations between military organisation and state organisation, especially underlining the dependence of the latter on the demands derived from the balance of power between States, a balance basically, if not exclusively, guaranteed by military force. ${ }^{27}$ Then, just after the end of the Great War, the Austrian economist Joseph Schumpeter, nowadays a classic in his discipline and one who, in contrast with others, never ignored the historical dimension of the problems he dealt with, could state that "taxes not only helped to create the state. They helped to form it". These taxes had been introduced to cover the growing military expenses of the European princes from the end of the Middle Ages. ${ }^{28}$

Seen nowadays with hindsight, Hintze's and Schumpeter's pioneering works clearly show how not only concepts, but also the burning questions of their time, were projected in historiography. In the former case, this was the state-building of the Second Reich, and in the latter, the fiscal crisis that was intensely debated on the eve of the creation of the First Austrian Republic.

However, the golden age of social history in the decades immediately after the Second World War relegated the State to the historiographic background. Obviously, this was linked to the rise of the French Annales and their belligerent rejection of political history, a political history adapted, and sometimes deliberately

\footnotetext{
26. I appropriate here the expressive utterance coined by Grendi, Edoardo. "Del senso comune storiografico". Quaderni Storici, 41 (1979): 698-707.

27. Hintze, Otto. "Military Organization and the Organization of the State", The Historical Essays of Otto Hintze, Felix Gilbert, ed. New York: Oxford University Press, 1975: 178-215. For more on Hintze: Schiera, Pierangelo. Otto Hintze. Naples: Guida, 1974.

28. Schumpeter, Joseph. "The Crisis of the Tax State", The Economics and Sociology of Capitalism, Richard Swedberg, ed. Princeton: Princeton University Press, 1991: 99-140, the quote on p. 108. For the context in which Schumpeter elaborated this work, shortly before becoming head of the Treasury in the first government of the Republic of Austria: McCraw, Thomas K. Prophet of Innovation: Joseph Schumpeter and Creative Destruction. Boston: Harvard University Press, 2007: 93-103.
} 
characterised to condense in the eyes of the annalists everything that served to identify the historiographic enemy, the adversary whose defeat was a condition for their own affirmation. However, I would like to draw attention to the fact that this disappearance or overshadowing of the State was not limited to the discipline of history. The same happened in all the so-called social sciences, just in the decades when history showed its greatest willingness for dialogue with these disciplines (and an even greater inclination to imitate them). It must also be said that this was to the detriment of its traditional proximity and collaboration with philology. It was only in the 1970s that the State returned to the foreground..$^{29}$ The emergence of American historical sociology, with its renewed interest in the question of the formation of the nation States, together with the rise of the New Institutional Economy, also in the USA, whose dominance in the field of the social sciences did nothing but reflect its condition as a new economic powerhouse and pre-eminent political power on the international stage after the Second World War, were two notable examples of this "return" of the State to the historiographic proscenium promoted from related research fields.

This phenomenon remained linked to warfare, with the war being fought then between the two blocks the post-war world had been divided into: the Cold War. In Europe, after 1968, "Western Marxism" seemed to have rediscovered that class struggle finally had to be fought in the political arena, and that also generated renewed attention towards the State as a subject of research. In America, from the 1950s, no less pragmatic considerations inspired what was called the "theory of modernisation". ${ }^{30}$ This, converted into foreign policy doctrine, was adopted by the US administration, most notably under Kennedy and Johnson in the 1960s, and applied to counter the attraction that communism could exert in Third World countries.

The "theory of modernisation" was an inevitable reference for the social sciences in those decades, one that they had to deal with, either to identify themselves with it, or to mark distances from it. In an autobiographical work, the anthropologist Clifford Geertz remembered its ubiquity until well into the 1970s. ${ }^{31}$ A dense institutional conglomerate of universities together with government agencies and private foundations was woven around it. The academy does not seem to have been precisely an ivory tower. The theory sprang from the distinction between traditional and modern societies, and postulated the existence of a series of states or stages through which the former, the traditional societies, became modern societies. The State had a relevant role in this development, as "the building of an effective

29. Skocpol, Theda. "Bringing the State back in: strategies of analysis in current research", Bringing the State back in, Peter B. Evans, Dietrich Rueschemeyer, Theda Skocpol, eds. Cambridge (UK): Cambridge University Press, 1985: 3-43.

30. See, for all, Gilman, Nils. Mandarins of the Future: Modernization Theory in Cold War America. Baltimore \& London: The Johns Hopkins University Press, 2003.

31. Geertz, Clifford. "An Inconstant Profession: The Anthropological Life in Interesting Times". Annual Review of Anthropology, 31 (2002): 1-19. 
centralized national state" constituted "a necessary condition for take-off". ${ }^{32}$ The basis for the theory was sought in European history, which thus served as a model that it was aimed to universalise.

In fact, what the "theory of modernisation" generated was a mirror relationship between the expectations that it wilfully projected into the future (the future of the poor non-aligned countries) and its reconstruction of the past (the past of the countries which managed to grow rich in the West), which thus inevitably tended to model the latter in line with, or under the influence of, those expectations. What it led to was a kind of "colonisation" also of the West's own past, of submitting this past to the present. However, historiographically speaking, the "theory of modernisation" has been considered one of "the three main schools of Western historical interpretation in the twentieth century", ${ }^{33}$ together with Marxism and the Annales, such was its influence on American historiography in the second half of the last century. ${ }^{34}$

It was in this intellectual climate that On the Medieval Origins of the Modern State was gestated by Joseph Strayer. Its first version dates from 1961 and it was finally published as the book we all know in 1970. ${ }^{35}$ While the 1950s in Europe had concluded with "the medieval dissolution of the State", which Giovanni Tabacco had dutifully detailed when reviewing the most important works about the postCarolingian period from around the middle of the century, ${ }^{36}$ the 1960s saw how the state creature was resurrected in America with no need to wait for the end of the Middle Ages, not as a finished reality, but rather as the budding of something "modern". The operation could well be described as a second episode of the "revolt of the medievalists", after the first one by another American historian, Charles Homer Haskins, who, in 1927, published The Renaissance of the Twelfth Century, ${ }^{37}$ which put back the start of "modernity", pace Burckhardt, to a fully medieval time.

32. Rostow, Walt Whitman. The Stages of Economics Growth: A Non-Communist Manifesto. Cambridge (UK): Cambridge University Press, 1960: 7.

33. Appleby, Joyce; Hunt, Lynn; Jacob, Margaret. Telling the Truth about History. New York 8 London: W.W. Norton \& Company, 1994: 78.

34. There were also examples of explicit reception in 1970s European historiography, as shown by Wehler, Hans-Ulrich. Teoria de la modernizzazione e storia. Milan: Vita e Pensiero, 1991 (original ed.: 1975). 35. Strayer, Joseph. On the Medieval Origins of the Modern State. Princeton: Princeton University Press, 1970: "On the Medieval Origins of the Modern State should be understood", Bruce Holsinger does not hesitate to state, "not simply as a contribution to the historiography of medieval political formation, but as a central text in the thriving corpus of modernization theory - one that exemplifies a compelling link between its historical claims and the ideological needs of the moment". Holsinger, Bruce. "Medievalization Theory: From Tocqueville to the Cold War". American Literary History, 22/4 (2010): 893-912, the quote on pp. 896-897. See also Cantor, Norman F. Inventing the Middle Ages. New York: William Morrow and Company, Inc., 1991: 277-286.

36. Tabacco, Giovanni. "La dissoluzione medievale dello stato nella recente storiografia". Studi medievali, 1/2 (1960): 397-446, later included in Tabacco, Giovanni. Sperimentazioni del potere nell'alto medioevo. Turin: Einaudi, 1993: 245-303.

37. Haskins, Charles Homer. The Renaissance of the Twelfth Century. Cambridge (USA): Harvard University Press, 1927. "The revolt of the medievalists" is, as is known, the title of the last chapter of the classic work by Ferguson, Wallace K. The Renaissance in Historical Thought: Five Centuries of Interpretation. New 
Strayer had been a student and disciple of Haskins, and would be the most loyal follower of the points of view of the master, who is held to be the initiator of NorthAmerican professional medievalism and with whom Strayer shared integrally "the project of making the Middle Ages the starting point for modern authority and modern liberty". ${ }^{38}$ While, regarding freedom, Haskins dated the birth of the "individual" to the $13^{\text {th }}$ century, regarding authority, Strayer also dated the first stirrings of the State to that same century. One could go as far as to say that Strayer, who simultaneously taught medieval history in Princeton and worked for the CIA, was the incarnation among medievalists of something like "the quiet American" of Graham Greene's novel. ${ }^{39}$ In any case, his elitist and paternalistic liberalism prolonged the naive liberal idealism that Haskins represented in the interwar period through the years of the Cold War.

On the Medieval Origins of the Modern State and a compilation of other shorter works by Strayer published in 1971, as a kind of conclusion to his career, were glowingly reviewed in Annales in 1972 by Bernard Guenée, who had begun to collaborate with the journal some years earlier, after Charles-Edmond Perrin, a former protégé of Marc Bloch and mentor of Georges Duby, had effusively greeted —as did Duby in Annales itself- the publication of Guenée's thesis in $1963 .{ }^{40}$ In 1972, Guenée had also just published the volume of the collection "Nouvelle Clio" about the late-medieval "States", one that would consecrate him as an essential reference hereafter. ${ }^{41}$ In the context of French historiography, this was the first attempt to resurrect annalistestyle political history, after the paralysis to which had been condemned because of the determined and combative bid by the journal for social history. It is worth citing Guenée, as he expressed himself in a truly programmatic article in 1964 in which he advocated the legitimacy of a history centred on the relations between rulers and the ruled although still rooted in social reality:

York: Houghton Mifflin Co., 1948. More recently, the motto gave rise to an examination of what remains of Haskins' proposals in the historiography of the recent decades in Melve, Leidulf. "'The revolt of the medievalists'. Directions in recent research on the twelfth-century renaissance". Journal of Medieval History, 32 (2006): 231-252. See also the recent Noble, Thomas F.X. "Introduction", European Transformations: The Long Twelfth Century, Thomas F.X. Noble, John Van Engen, eds. Notre Dame, Indiana: Notre Dame University Press, 2012: 1-16.

38. Freedman, Paul; Gabrielle M. Spiegel. "Medievalism Old and New: The Rediscovery of Alterity in North American Medieval Studies". American Historical Review, 103/3 (1998): 677-704, 683.

39. For his fictional character, the British novelist seems to have been inspired by a real person, increasingly notorious in the 1950s, whose personality and adventures as an agent of the American intelligence services also serves as a thread in the work of historical reconstruction by Nashel, Jonathan, Edward Landsdale's Cold War. Amherst EBoston: University of Massachusetts Press, 2005. For Strayer's links with the CIA and his work as an assessor for the Agency, see Holsinger, Bruce. "Medievalization Theory...": 897-899.

40. Guenée, Bernard. "Pouvoir politique et féodalité". Annales Économies Societés Civilisations, 27/3 (1972): 690-691; Guenée, Bernard. “Les origines médiévales de l’État moderne". Annales Économies Societés Civilisations, 27/3 (1972): 704; Perrin, Charles-Edmond. "Tribunaux et gens de justice dans le bailliage de Senlis à la fin du moyen âge". Journal des savants (1965): 515-530; Duby, Georges. "Institutions et Société: Une monographie pleine de sève". Annales Économies, Societés, Civilisations, 19/4 (1964): 795-798.

41. Guenée, Bernard. L'Occident aux XIV et XVe siècles: Les États. Paris: Presses Universitaires de France, 1971. 
Cette histoire, il faut la nommer. Histoire administrative, histoire institutionelle, histoire des institutions ne conviennent pas. Ce ne sont que des parties du tout qu'on veut définir. Histoire politique conviendrait peut-être, mais le mot a été pris dans un sens si étroit, et si moqué, depuis si longtemps, qu'il serait sans doute responsable de fâcheux malentendus. Pourquoi ne pas parler, comme H. Pirenne et M. Bloch ont pu le faire, d'histoire de l'État? L'expression n'est pas trop usée; elle est bien vague mais n'est pas compromise; elle nécessite une définition mais se prête à toutes les ambitions. En attendant qu'un esprit inventif mette en circulation un nouvel adjectif, ou que le mot 'politique' ait terminé son purgatoire et réintegré le paradis de la vraie histoire, je continuerai à parler d'histoire de l'État. ${ }^{42}$

At the start of the 1970s, the times seemed to help. I have mentioned above the "return of the State" as a characteristic phenomenon of the decade in the field of social sciences. Guenée could regale Strayer from the pages of Annales and congratulate himself openly for having an influential ally on the other side of the Atlantic. Duby himself, recently arrived in the Sorbonne, surprised all and sundry by accepting Gallimard's commission to write Le dimanche de Bouvines, with which, not just political history, but also battle history, the much-maligned éveneméntielle history, seemed to have reached the point of rehabilitation..$^{43}$ After Duby published the book in 1973, the review by Guenée, again in the pages of Annales, put things in their place and cleared up misunderstandings: the event, réhabilité et même glorifié, est enraciné dans cette histoire des structures et des mentalités sur laquelle a porté l'essentiel de l'effort de l'école historique française dans les cinquante dernières années. ${ }^{4}{ }^{4}$

However, one could think that, in a certain sense, Guenée arrived late. It would not be around the "history of the State", but rather that of power, an even vaguer, imprecise and elusive term, where the greatest capacity to renew political history would be concentrated in the following decades. And the brilliant idea was soon at home in the early 70s, endorsed by who was already a member of the editorial board of Annales, Jacques Le Goff. ${ }^{45}$ The 1970s would see the end of many of the

\footnotetext{
42. "This history requires a name. Administrative history, institutional history, history of the institutions, are of no use. They are no more than parts of the whole that we wish to define. Perhaps political history would serve, but the name has been understood in such a narrow sense and was so long ago turned into an object of ridicule that it would lead to bothersome misunderstandings. Why do we not talk, as $\mathrm{H}$. Pirenne and M. Bloch did, about history of the State? The expression is not too worn; it is very vague and does not commit; it needs a definition but it lends itself to any purpose. While waiting for an inventive spirit to put a new adjective into circulation, or for the word "politics" to end its purgatory and return to the paradise of true history, I will continue to use history of the State". Guenée, Bernard. "L'histoire de l'État en France à la fin du Moyen Age vue par les historiens français depuis cent ans". Revue historique, 232/2 (1964): 331-360, 345, then also in Politique et histoire au moyen-âge: recueil d'articles sur l'histoire politique et l'historiographie médiévale (1956-1981). Paris: Publications de la Sorbonne, 1981: 3-32.

43. Duby, Georges. La historia continúa. Madrid: Debate, 1992: 120-127.

44. "rehabilitated and even glorified, is rooted in this history of the structures and mentalities to which the bulk of the French historical school has devoted its efforts over the last fifty years". Guenée, Bernard. "Le dimanche de Bouvines. 27 juillet 1214". Annales Économies Societés Civilisations, 29/6 (1974): 15231526.

45. Fernández Albadalejo, Pablo. "La historia política: de una encrucijada a otra”, Balance de la historiografía modernista 1973-2001: Actas del VI Coloquio de Metodología Histórica Aplicada (Homenaje al profesor Antonio Eiras Roel). Santiago de Compostela: Xunta de Galicia, 2003: 479-488.
} 
certainties that the triumphant social history had endorsed in the post-war decades, also those that constituted the marks of identity or the spirit of Annales. The decade would also end announcing the rise of new proposals and new paths that would grow in the 1980s and that, together with the old and more or less renovated paths, have made up the lush historiographic landscape in which we still move.

It was then, in the 1980s, when Jean-Philippe Genet took over from Strayer and Guenée (who had directed his thesis) to continue proposing a consideration of the political history of the final centuries of the Middle Ages from a state perspective, of the "genesis of the modern State" as we would now say. Naturally, this did not mean that there were no differences between these three historians. One need only mention the different consideration that they each gave to war as a factor in State development: as a curb or obstacle in Strayer's case to the main stimulus and motor for Genêt, passing through the scant emphasis that Guenée gave to this question to say the least. Genet himself gives a dense account of his more complex and nuanced approach in the second half of the 90s, when he assesses the well-known and fruitful research programmes he encouraged, reviewing the very diverse traditions and fields of study that converge in his project, which, at the same time, reflected the plurality of independent routes characteristic of the historiography in the last two decades of the $20^{\text {th }}$ century: Genet's proposal was that of une histoire large (comparative et dans le long terme) du politique (l'État), ancrée profondément dans le social et l'èconomique (le féodalisme), étroitement liée à l'étude des acteurs sociaux (la prosopographie) et à l'histoire culturelle. ${ }^{46}$

However, what unites Strayer, Guenée and Genet is a shared ascription to a logic of state building when dealing with the political history of the $12^{\text {th }}$ century onwards that is still nowadays a dominant paradigm, although not free of problems (as John Watts reminds us in his recent book) or of alternatives (as we shall see below). Of course, the mere use of the word State or the phrase "modern State" is not nowadays sufficient indication to share this paradigm. The lively debate about this question in recent decades, partly fostered by Genêt's proposal, has meant that things are currently somewhat more complicated. ${ }^{47}$ That debate seems today to have mitigated a certain tendency in the 80-90s to generalize, which surely facilitates an assessment that is less contingent, more empirical and more focused. Of greater significance than the use of the noun State, alone or accompanied by the adjective modern or others, is the use of supposedly descriptive and neutral categories (or of contrasts whose value is assumed, like the very common one between public and private) which reveals the presence of the state logic, at least unilateral, as Watts

\footnotetext{
46. "a broad history (comparative and in the long term) of the political (the State), anchored deeply in the social and economic (feudalism), closely linked to the study of the social actors (the prosopography) and cultural history". Genet, Jean-Philippe. "La genèse de l'État moderne: Les enjeux d'un programme de recherche". Actes de la recherche en sciences sociales, 118 (1997): 3-18, the quote on pp. 10-11.

47. I know no better approach to the trajectory traced by the notion of modern State in $20^{\text {th }}$-century historiography than the one offered by Benigno, Francesco. Las palabras del tiempo: un ideario para pensar históricamente. Madrid: Cátedra, 2013: 199-222.
} 
indicates, and which, by determining the questions, conditions the answers the sources are able to offer.

\section{Jurisdictional political culture}

In a way, Watts' statement that, apart from French, Spanish historiography has been the most permeable to the interpretative framework centred on the "genesis of the modern State" proposed by Genet can come as a surprise. ${ }^{48}$ The surprise is due to the fact that from as early as 1960, related or relevant works in Spanishspeaking territories can be identified that could have marked a different orientation and, ultimately, one closer to the posture that the English historian sustains. I am thinking about the latter work of Vicens Vives, ${ }^{49}$ or the "composite monarchies" of the Hispanist John Elliot, ${ }^{50}$ to cite two milestones that cover practically all the second half of the $20^{\text {th }}$ century. However, it is true that both Vicens and Elliot concerned themselves with the $16^{\text {th }}$ and $17^{\text {th }}$ centuries; and effectively, it is precisely and perhaps paradoxically in the early-modernist historiography where critical or revisionist positions about the paradigm of the modern State, its logic and architecture, have been expressed more clearly and with more verve. As a result of this, and about the theme of war that concerns us here, Bartolomé Yun, for example, can state in a recent text, that in early modern Europe war was not always a condition for the development of States or fiscal regimes nor did all wars produce this effect. ${ }^{51}$

That the old regime's political organization itself could be understood as a proper state-level organization is what others squarely question. Hence, Yun prefers to talk about "fiscal regimes", and not "fiscal states", before the $19^{\text {th }}$ century. Hence, one can also sometimes garner the impression that the medievalists are pursuing a chimera,

48. Evidence for this in Fuente, María Jesús. “El Estado ha muerto, ¡viva el Estado! Debates historiográficos sobre el Estado en la Edad Media". Revista de Historiografía, 9 (2008): 33-49. See also, for contrast, the observations from the start of the same decade by García de Cortázar, José Ángel. "Elementos de definición de los espacios de poder en la Edad Media", Los espacios de poder en la España medieval. XII Semana de Estudios Medievales (Nájera, 2001), José Ignacio de la Iglesia, José Luis Martín, coords. Logroño: Instituto de Estudios Riojanos, 2002: 13-46.

49. Vicens Vives, Jaime. "Estructura administrativa estatal en los siglos XVI y XVII", Obra dispersa: España, América, Europa. Barcelona: Vicens-Vives, 1967: 359-377, also in Coyuntura económica y reformismo burgués. Barcelona: Ariel, 1969: 99-141. For the decisive impact of Vicens' work had had on the change of course in the following years by the Italian historiography interested in this problem, including that focussed on the late Middle Ages, see Isaacs, Ann Katherine. "Twentieth Century Italian Historiography on the State in the Early Modern Period", Public Power in Europe: Studies in Historical Transformations, James S. Amelang, Sigfried Beer, eds. Pisa: Edizioni Plus, 2006: 17-38.

50. Elliot, John H. “A Europe of Composite Monarchies". Past and Present, 137 (1992): 48-71, with a Spanish translation in Elliot, John H. España en Europa: Estudios de historia comparada. Valencia: Universitat de València, 2003: 65-91. And see also Elliot, John H. Haciendo historia. Madrid: Taurus, 2012, especially chapter 2.

51. Yun, Bartolomé. "Introduction: the rise of the fiscal state in Eurasia from a global, comparative and transnational perspective", The Rise of Fiscal States: A Global History, 1500-1914, Bartolomé Yun, Patrick K. O’Brien, eds. Cambridge (UK): Cambridge University Press, 2012: 1-36. 
focussed on reconstructing the genesis of something whose reality is, in the best of cases, problematic. This is perhaps a perverse effect, the undesired consequence of an excess of chronological specialisation that not even the great collective work led by Genêt and Wim Blockmans between the 1980s and 90s managed to palliate, given that, as Jacques Krynen later mentioned, that work had allowed medievalists and early-modernists to work beside each other, but not together. Krynen added that le plus grand service que les médiévistes pourraient rendre au Moyen Age serait de cesser de faire exclusivement du Moyen Age... Il nous faut briser la chronologie... Se souvenir que Marc Bloch l'a fait, étudiant un miracle royal. ${ }^{52}$

In truth, until now, the early-modernists seem more sensitive to what should be contemplated as the historiographic consequences of the current crisis of the nation-state, and for that reason, more aware that this was not the inevitable fate or the obligatory end. They showed more willingness than the late-medievalists to explore the aptitudes and possibilities of a "political history without [a] State", ${ }^{53}$ although this could end up being less strange to the latter by only looking at the High Middle Ages and endeavouring not to see only chaos, arbitrariness or confusion, a panorama that would only have begun to change with the modernising impulse that would have meant the renaissance of the $12^{\text {th }}$ century, also politically.

From the revisionist viewpoint, the $12^{\text {th }}$ century marked a turning point with regard to political history anyway. However, it was not one that led to institutional development and growing state political culture, but rather to the deployment and configuration of an institutional complex and a jurisdictional political culture that, since the 1980s, has been brought to light by a renewed history of institutions whose leading representatives are from the countries of southern Europe and whose echo has also reached the early-modernists more than it has medievalists.

Whatever else, we have to thank these historians (primarily, but not only, legal historians) at least for having identified the issues accurately and raised the problems clearly, which is quite something in a terrain where the conceptual vagueness of some approaches had, for a long time, no alternative but the deductive theoretical elaborations of others. In contrast, the jurisdictional model or paradigm has been built looking to the conceptual universe and the argumentative rhetoric of the sources themselves, and thus addressed through their own discursive context. Among these, the ones that should be considered of a doctrinal nature (a not very theoretical doctrine, but very attached to the praxis, in which that world was also very different from ours) were the result of that "mysterious science" as Edward Gibbon contemptuously dismissed it, in other words, of the science of law in its

\footnotetext{
52. "the best the medievalists can do for the Middle Ages would be to stop doing exclusively the Middle Ages... We must thwart the chronology... Remember that Marc Bloch has done so studying a real miracle". Krynen, Jacques. "La souveraineté royale", Les tendances actuelles de l'histoire du Moyen Âge en France et en Allemagne, Jean-Claude Schmitt, Otto Gerhard Oexle dirs. Paris: Publications de la Sorbonne, 2002: 299-302.

53. Schaub, Jean-Frédéric. “L'histoire politique sans l'État: mutations et reformulations”, Historia a debate, Carlos Barros ed. Santiago de Compostela: Xunta de Galicia, 1995: III, 217-235; García Monerris, Carme; García Monerris, Encarna. "Fragmentos de Monarquía: La possibilitat d'una història política sense estat". Recerques: història, economía i cultura, 32 (1995): 103-111.
} 
ius commune stage, a science whose origins can be traced back precisely to the $12^{\text {th }}$ century $^{54}$ and which was developed from the study of, at times, centuriesold material, ancient reports and norms which, envueltas en farragosos volumenes de privados y oscuros intérpretes, forman aquella tradición de opiniones que en gran parte de Europa tiene todavía el nombre de leyes, as the Milanese Cesare Beccaria, a close contemporary of Gibbon, also wrote. ${ }^{55}$ "[The] dregs of the most barbarous ages", as the latter concluded. It was the mentality of the Enlightenment, whose laudable aims also served to cement the wall of misunderstanding, if not of oblivion, that would subsequently rise between that world and modern historiography.

It was left to late medieval and early modern scientia iuris to ascertain and organize the complex and ever-evolving problematic fabric of overlapping and mutually adapting powers that coexisted in the same territories. And it is by virtue of that mission that the law of the time can today be considered the most suitable (being the most direct) approach to the composition, characteristics and logic of that fabric. It might be objected, perhaps, that its proponents' elaborations are but a construct, to which it could be answered that it is but the necessary theoretical framework that, explicitly or implicitly, also underlies any reconstruction and historical analysis. Unlike the assumptions and deductions many historiographic works rely on, however, some of the most salient features of the jurists' activity during the period under consideration - above all, their course of action, not systematic but case-based and topical, as well as their purpose, not directly normative, in the sense that their resolutions were not necessarily binding, even less final, but rather simply shaping the communis opinio (the prevailing opinion among experts, always open to contradiction) - make it preferable to consider the results of that activity as the best way today para entender, a su través, las prácticas y el ejercicio del poder. ${ }^{56}$ In this respect, it is worth recalling the words of Patrick Geary, nearly thirty years ago:

54. Quaglioni, Diego. "Introduzione. La rinovazione del diritto", Il secolo XII: la "renovatio" dell'Europa cristiana, Giles Constable, Giorgio Cracco, Hagen Keller, Diego Quaglioni, eds. Bologna: Il Mulino, 2003: 17-34.

55. "wrapped in cumbersome volumes of private and dark interpreters, they make up that tradition of opinion that still has the name of laws in much of Europe". Pardos, Julio A. "El mundo nuevo del derecho", Historia de Europa, Miguel Artola, dir. Madrid: Espasa, 2007: I, 796-804. The quote from Gibbon is from the last paragraph of chapter 44 of The History of the Decline and Fall of the Romen Empire; the one by Beccaria, from the first paragraph of Dei delitti e delle pene. I cannot resist adding another expressive judgement that the Justinian compilation merited from another contemporary, the Napolitan jurist Gaetano Filangieri, author of La scienza della legislazione: these were "leggi d'un popolo prima libero e poi sciavo, compilate da un giureconsulto perverso sotto un Imperatore imbecille" ("laws of a people first free, then enslaved, compiled by a perverse jurisconsult under an imbecile of an Emperor"), cited by Lazzarich, Diego; Borrelli, Gianfranco. "I Borbone a San Leucio: un esperimento di polizia cristiana", Alle origini di Minerva trionfante: Caserta e l'utopia di S. Leucio: la costruzione dei siti reali borbonici, Imma Ascione, Giuseppe Cirillo, Gian Maria Piccinelli, eds. Rome: Ministero per i beni e le attività culturali: Direzione generale per gli archivi, 2012: 345-372, specially 347.

56. "to understand, through them, the practice and exercise of power". Vallejo, Jesús. "El príncipe ante el derecho en la cultura del ius commune", Manual de historia del derecho. Valencia: Tirant lo Blanch, 2012: 152. The same author introduces in the best way imaginable the modes of reasoning and argumentation of the jurists of the ius commune in "Derecho como cultura: equidad y orden desde la óptica del ius commune", Historia de la propiedad: patrimonio cultural. III Encuentro interdisciplinar (Salamanca, mayo 2002), 
Les médiévistes doivent commencer à élaborer d'autres schémas conceptuels et les plus utiles, à nos yeux, se truvent dans la riqche littérature, souvent pleine de contradictions, de l'anthropologie juridique. Les historiens du Moyen Age ne sont, en aucun cas, les premiers à découvrir les sociétés aux prises avec des conflits et de diffèrends à résoudre sans l'aide d'institutions juridiques centralisés et impersonnelles qui soient capables de rendre des verdicts définitifs et de les faire respecter. Des telles sociétés sont nombreuses mais, si l'Europe médiévale diffêre radicalement $d u$ monde des Barotse du Nord Zimbabwe ou des Kung Bushmen du Kalahari expérience des anthropologues qui étudient la fa on dont ces sociétés traitent les tensions sociales peut nous permettre élaborer des concepts pour comprendre Europe médiévale. ${ }^{57}$

Why not start simply by dealing with concepts from the sources themselves, without translations that end up being misleading? For this, it is worth taking into consideration the medieval and early modern idea of law. Law was not then an expression of power, but rather legal order (ordenamiento), social emanation and not a political imposition, to sum up, auto-organizzazione prima che norma as Paolo Grossi has insisted..$^{58}$ There was neither confusion between ius and lex nor a monopoly on its production, as would occur much later with the arrival of the State. The normative force of law, which it had, did not come about so much through the legislative path but was more jurisprudential and doctrinal. Then the law was, in short, a reality

Salustiano de Dios, Javier Infante, Ricardo Robledo, Eugenia Torijano, coords. Madrid: Centro de Estudios Registrales, 2003: 53-70. See also Viehweg, Theodor. Tópica y jurisprudencia. Madrid: Taurus, 1964, 1986; Hespanha, António Manuel de. "Early Modern Law and the Anthropological Imagination of Old European Culture", Early Modern History and the Social Sciences: Testing the Limits of the Braudel's Mediterranean, John A. Marino, ed. Kirksville: Truman State University Press, 2001: 191-204, maxime 201 and following.

57. "The medievalists must begin to draw up other conceptual schemes, and to our way of thinking, the most useful are to be found in the rich literature, often full of contradictions, of legal anthropology. In no case are the historians of the Middle Ages the first to discover societies that have to resolve their conflicts and differences without the help of centralised legal institutions in a position to issue and enforce final verdicts. Such societies abound, but while medieval Europe differs radically from the world of the Barotse of Northern Zimbabwe or the Bushmen of the Kalahari, the experience of anthropologists studying how these companies manage social tensions can enable us to develop concepts for understanding medieval Europe". Geary, Patrick J. "Vivre en conflit dans une France sans État: typologie des mécanismes de règlement des conflits (1050-1200)". Annales. Économies Sociétés. Civilisations, $41 / 5$ (1986): 1107-1133 (especially 1109-1110).

58. "self-organisation rather than norm". Grossi, Paolo. Il diritto tra potere e ordinamento. Naples: Editoriale Scientifica, 2005: 9. The essential reference here is obviously Grossi, Paolo. L'ordine giuridico medievale. Rome-Bari: Laterza, 1995, but also take advantage of other works by the author now conveniently collected in the anthology Paolo Grossi, ed. Guido Alpa. Rome-Bari: Laterza, 2011, especially "Ordinamento" (46-57), "Un diritto senza Stato (la nozione di autonomia come fondamento della costituzione giuridica medievale)" (66-82) and "Dalla società di società alla insularità dello Stato: fra Medioevo ed Età moderna" (88-107). The far from unambiguous term ordinamento (and its Spanish derivation ordenamiento) is deep-rooted in the juridical traditions of a number of continental European nations, but only recently incorporated into others such as the English, where it is habitually translated as "legal order". In this respect, see Itzcovich, Giulio. "Legal Order, Legal Pluralism, Fundamental Principles. Europe and Its Law in Three Concepts". European Law Journal, 18/3 (2012): 358-384. For Grossi's usage of the term ordinamento, indebted to Santi Romano's institutionalism, see Locchi, Maria Chiara. "Brief reflections on legal pluralism as a key paradigm of contemporary law in highly differentiated western societies". Revista Brasileira de Direito, 10/2 (2014), 74-84. 
prior to power. This is the perspective that Grossi has emphasised as necessary to understand the pre-contemporary legal order and this is, however, not usually even suspected by a mentality like ours, forged on the idea that power necessarily has to precede the law. This could undoubtedly be used in its own benefit, but the production of law was not a vital function of power prior to the appearance of the State, the creation and establishment of the former was not part of the physiology of the latter, as would happen at a later stage of European history with the advent of the state subject. Thus the medieval and current conceptions of law (at least the dominant ones in the latter case) are not comparable with each other. This means that, without careful translation, the categories of each conception are totally inadequate, if not aberrant, for explaining one through the other.

Regarding the historiographic practice, an important consequence of the above is that law understood as legal order, in the sense thus defined, is not identified with a reductive and simplistic vision of social complexity, like that which tends to endorse the statist conception of law typical of legal positivism and informed the old, $19^{\text {th }}$ century history of institutions, rightfully maligned in the $20^{\text {th }}$ century by social historians, very especially by medievalists. On the contrary, that understanding expresses that complexity in the legal pluralism and the pullulare di ordinamenti $i^{59}$ it gives rise to and which is a fundamental fact at the basis of the jurisdictionalist perspective of the medieval and early modern societies.

However, the law was no more than one, and not the most important, of the many devices destined to guarantee order in those societies. United inextricably to law (or even above the law in cases of conflict with it), religion, then socially equipped with its full prescriptive power, also fulfilled this task. ${ }^{60}$ Crime was then no more serious than $\sin .{ }^{61}$ In fact, at first, they were indistinguishable, and the primacy of religion meant a conception of order, of social order thus integrated into the natural order, as something preceding the law and unavailable to this. Law was not then seen as creating order; it was only used to make this order clear. ${ }^{62}$ Its position was assuredly subordinate, because love of God and one's neighbour (charity, theological virtue) prevailed or should prevail in its social consideration over justice (cardinal virtue), although the latter was also identified with the Creator and Supreme Judge. That is

59. "proliferation of legal orders". Grossi, Paolo. “Ordinamento...": 54.

60. Still essential for these questions, Clavero, Bartolomé. Antidora: antropología católica de la economía moderna. Milan: Giuffrè, 1991; Clavero, Bartolomé. "Beati dictum: derecho de linaje, economía de familia y cultura de orden". Anuario de Historia del Derecho Español, 63-64 (1993-1994): 7-148.

61. With different viewpoints: Clavero, Bartolomé. "Delito y pecado: noción y escala de transgresiones", Sexo barroco y otras transgresiones premodernas, Francisco Tomás, coord. Madrid: Alianza, 1990: 57-89; Prodi, Paolo. Una storia della giustizia: dal pluralismo dei fori al moderno dualismo tra coscienza e diritto. Bologna: Il Mulino, 2000; Morin, Alejandro. "Pecado e individuo en el marco de una antropología cristiana medieval". Bulletin du Centre d'études médiévales d'Auxerre, Hors série 2. (2008) <http://cem.revues.org/9552>.

62. Petit, Carlos; Vallejo, Jesús. "La categoria giuridica nella cultura europea del Medioevo", Storia d'Europa. 3. Il Medioevo: secoli V-XV, Gherardo Ortalli, ed. Turin: Einaudi, 1994: 721-760; Hespanha, António Manuel. Cultura jurídica europea: síntesis de un milenio. Madrid: Tecnos, 2002: 58 and following; Hespanha, António Manuel. "As cores e a instituição da ordem no mundo do antigo regime". Phronesis: Revista do Curso de Direito da FEAD, 6 (2010): 9-24. 
the reason for the frequent presence in our sources, including the sources of practice or social documents, of a language of love and lovelessness, which historians have not always taken seriously or have even ignored, uncomfortable with a vocabulary that seemed to be a remnant of naivety. This was especially so if it was expressed in the vernacular, in other words, once Western Europe had taken the supposedly irreversible path to institutional modernity, even thought the reality could seem contradictory.

The same vocabulary in its Latin version and in documents from the High Middle Ages was less surprising. Amor and amicitia could appear in these, concerning the most serious questions and without embarrassing the historian, with their own semantic and figurative load, since not for nothing were the writers often men of the Church, devoted to God; but this was also because this was prior to the beginnings of said modernity. It was then concluded that, on the basis of the moral value of (more or less ritualized) love and friendship, ways of solving conflicts could efficiently be developed which would eventually be made obsolete by the development and imposition of increasingly stable and rational legal institutions and of ever more centralized dependency. The post-Carolingian guerrae were settled, not with the simple establishment of a neutral peace, but rather with the reestablishment of the amor between the sides in the conflict through the voluntary action as arbiters or mediators of pairs of opponents. As is known, this was the subject of the abovementioned well-known article by Patrick Geary, then the spokesperson for a historiographic current which has come to be called the "American School" in the study of medieval conflicts and social order. ${ }^{63}$ The title of one of the first emblematic texts in this current resorted to an apothegm contained in the Leges Henrici Primi, a compilation drawn up in England in the early $12^{\text {th }}$ century: Pactum legem vincit et amor iudicium. ${ }^{64}$ Nowadays we know, however, of the lasting validity of the principle that supported such a legal axiom, a validity not only limited to the High Middle Ages, but lasting throughout all the Middle Ages ${ }^{65}$ and beyond. ${ }^{66}$ The love referred

63. Conflict in Medieval Europe: Changing Perspectives on Society and Culture, Warren C. Brown, Piotr Górecky, eds. Aldershot: Ashgate, 2003.

64. White, Stephen D. "Pactum... Legem Vincit et Amor Judicium: The Settlement of Disputes by Compromise in Eleventh-Century Western France". The American Journal of Legal History, 22 (1978): 281-308, now also in White, Stephen D. Feuding and Peace-Making in Eleventh-Century France. Aldershot: Ashgate, 2005.

65. Clanchy, Michael. "Law and Love in the Middle Ages", Disputes and Settlements: Law and Human Relations in the West, John Bossy, ed. Cambridge (UK): Cambridge University Press, 1983: 47-67; Roebuck, Derek. Mediation and Arbitration in the Middle Ages: England 1154 to 1558. Oxford: Holo Books, 2013; Smail, Daniel Lord. "Telling Tales in Angevin Courts". French Historical Studies, 20/2 (1997): 183-215; id. The Consumption of Justice: Emotions, Publicity, and Legal Culture in Marseille, 1264-1423. Ithaca: Cornell University Press, 2003; Vallejo, Jesús. “Amor de árbitros: episodio de le sucesión de Per Afán de Ribera el Viejo", Fallstudien zur spanischen und portugiesischen Justiz: 15. bis 20. Jahrhundert, Johannes-Michael Scholz, ed. Frankfurt am Main: Vittorio Klostermann, 1994: 211-269.

66. Bossy, John. "Postscript", Disputes and Settlements: Law and Human Relations in the West, John Bossy, ed. Cambridge (UK): Cambridge University Press, 1983: 287-293; Hespanha, António Manuel. La gracia del derecho: economía de la cultura en la Edad Moderna. Madrid: Centro de Estudios Constitucionales, 1993: maxime chap. 1; Raggio, Osvaldo. "Visto dalla periferia. Formazioni politiche di antico regime e Stato moderno", Storia d'Europa. 4. L'età moderna: secoli XVI-XVIII, Maurice Aymard, ed. Turin: Einaudi, 1995: 
to should be understood not so much as a subjective mood but more as an objective reality, in the same sense that colours are thought of not so much as a perception of the subject, but more as a quality of the objects. Love is affection, inclination, yes, but it must not submit to the will, which is potencia ciega. ¿Qué se puede esperar de un hombre que tiene más respeto a lo que su voluntad inclina que a lo que la ley de Dios le obliga? ${ }^{67}$. It was not the viewpoint of the subject, of the individual, that was then privileged socially and institutionally to negotiate and integrate itself into the world.$^{68}$ For him to control his own life - to use a common expression today-, it would have been necessary to abolish the ordenamiento compuesto, ${ }^{69}$ at the same time religious and legal, in which he was previously immersed.

In its various specific manifestations, the European social and political order of the $12^{\text {th }}$ through the $18^{\text {th }}$ centuries was, in effect, not a compound of individuals but one of persons. Persons who could be identified with individuals, but were not to be mistaken for them; who could be multiplied within a single individual; or require a plurality of them to be constituted, on the other hand. Individuals, in short, were no more than players of one or more roles; and it was the latter, not the former, who held rights and duties, or rather, privileges and functions. The former (the privileges) were expressions of diversity and inequality, and the individuals shared in these, not as such, but rather because of their status or social condition, that is to say, the role or roles they could play, as these roles could also vary, in either time or space. These were the only states (understood as status) existing then. The latter - the functions - responded to an idea of unity that was not equivalent to homogeneity, but rather of an ideally harmonic aggregate of heterogeneous fragments. These were pieces or fragments that, at the same time as they pursued their own aims, contributed to the ordered working of the whole they formed part of. Only in these cases, persons were identified with a body, to the point of becoming it, not a material body but a mystical one, just as the Church was said to be a corpus mysticum. It was, then, an immaterial and immortal body, originated either in a succession of individuals with the same dignity or in a coeval plurality of them in a corporation. And society as a whole, made up of those bodies and with

483-527; Niccoli, Ottavia. Perdonare: idee, pratiche, rituali tra Cinque e Seicento. Rome-Bari: Laterza: 2007; Stringere la pace: teorie e pratiche della conciliazione nell'Europa moderna (secoli XV-XVIII), ed. Paolo Broggio, Maria Pia Paoli. Rome: Viella, 2011; The Charitable Arbitrator: How to Mediate and Arbitrate in Louis XIV's France, ed. Derek Roebuck. Oxford: Holo Books, 2002; Garriga, Carlos. “Sobre el gobierno de la justicia en Indias (siglos XVI-XVII)". Revista de Historia del Derecho, 34 (2006): 67-160, especially 143.

67. Covarrubias, Sebastián de. "Voluntad", Tesoro de la lengua castellana, o española. Madrid: Luis Sánchez impresor, 1611: 76v. And see Hespanha, António Manuel. "La senda amorosa del derecho: amor y iustitia en el discurso jurídico moderno", Pasiones del jurista: amor, memoria, melancolía, imaginación, Carlos Petit, ed. Madrid: Centro de Estudios Constitucionales, 1997: 23-56; Hespanha, António Manuel. “Early Modern Law and the Anthropological Imagination..."; Hespanha, António Manuel de. "As cores e a instituiçao da ordem...".

68. Alessi, Giorgia. Il soggetto e l'ordine: percorsi dell'individualismo nell'Europa moderna. Turin: Giappichelli, 2006; Clavero, Bartolomé. Happy Constitution: cultura y lengua constitucionales. Madrid: Trotta, 1997: 11-40. 69. "composite order". Clavero, Bartolomé. "Beati dictum...": 119. Some convergence can now be appreciated, at least in the approach, in Fletcher, Christopher; Oates, Rosamund. "Afterword: Religious Thought, Political Practices, 1200-1600". Cultural and Social History, 6/3 (2009): 297-304. 
each of them playing their appointed parts, could be conceived after that organicist pattern (this would become an iconographic as well as a discursive motif, as is well known) and also imagined as a body, that is, as a person. It was these persons then, with a body and of different importance, who shaped that political and social order. About the single individual, not being a person as such, the only socially relevant element was his soul. ${ }^{70}$

It should be added that this corporate composition, as it is customary to say (with the risk, however, of misunderstandings), was considered part of a natural order and, therefore, unavailable to any political power, for whom the multiplicity of bodies and the relative autonomy of each of them was an irreducible fact. The corporations that, like the cities, had a territorial base, together with the seigneurial entities, could thus survive as political subjects throughout the time of validity of that conception of order, not as vestiges or remains from a certain moment, but rather as consubstantial elements of the same.

On the other hand, a feature of that way of understanding the social and political order, in which the autonomy of the pieces that made up the whole is concerned, was their recognized ability to provide their own legal order, with the result that, from this point of view, the whole was a complex mosaic or a far from homogeneous aggregate of iura propria. And this was the most visible manifestation of the iurisdictio that, to a varying extent, was recognised equally as consubstantial to each body (corpus, societas, communitas, universitas, civitas, respublica...) and that was exercised by its head (pars principans). Jurisdiction (iurisdictio and its semantic field in that context, not in ours) was the word that then effectively designated political power. ${ }^{71}$ The holder was the person who held jurisdiction, each in his own field, but without any hierarchy being able or empowered to suspend or annul what corresponded to each within his own sphere. The consequence can be no other than an understanding of the political framework as a constellation of republics, constantly obliged because of the circumstances to negotiate the composition of the whole, this being the expression of polycentrism that then characterised the possession and exercise of political power.

Iurisdictio is first and foremost judicial power, and its holder is primarily the judge, whose activity is mainly focussed on resolving conflicts, giving to each his due (suum cuique tribuere, as the definition of justice states in the Digesto by Ulpianus and that Thomas Aquinas would make his own), in other words, ensuring that each one was in his corresponding place within the pre-established order, the natural order of things. However, iurisdictio was also regulatory power, understood as the power

70. Clavero, Bartolomé. Tantas personas como estados: por una antropología política de la historia europea. Madrid: Tecnos, 1986; Clavero, Bartolomé. "Almas y cuerpos: sujetos del derecho en la Edad moderna". Studi in memoria di Giovanni Tarello, 1. Milan: Giuffrè, 1990: 153-171; Hespanha, Antonio Manuel. “Early Modern Law and the Anthropological Imagination...": 193 and following.

71. The fundamental reference here has to be to none other than Costa, Pietro. Iurisdictio: semantica del potere politico nella pubblicistica medievale (1100-1433). Milan: Giuffrè, 1969, 2002; and, in his wake, Vallejo, Jesús. Ruda equidad, ley consumada: concepción de la potestad normativa, 1250-1350. Madrid: Centro de Estudios Constitucionales, 1992. 
to interpret, adapt and specify this same natural order in precise circumstances, not as a prerogative to create a new order ex novo. Thus, it corresponded to the holder of the iurisdictio to ensure the maintenance and conservation of an order that preceded him and proceed to restore this in case it was violated, and always doing so in line with the requirements and guarantees of a procedural act. Hence, it has been possible to talk about a medieval-origin concepción panjudicial del gobierno, ${ }^{72}$ or rappresentazione giustiziale del potere ${ }^{73}$ that survived throughout the early modern period. Only by resorting on exceptional, justified and equally regulated occasions, to the potestas absoluta accorded in European kingdoms of the time to the incumbent of highest jurisdiction, was the latter able to rule without abiding by the judicial guidelines governing his habitual conduct and course of action; and only by also appealing to their domestic potestas oeconomica, by virtue of the republic being likened to a household (the social order's basic cell, subject to the pater familias' discretionary power) were the holders of jurisdiction entitled to act without the restrictions of its exercise.

Very briefly, these were the conceptions and values that sustained the social and institutional order prior to the revolutions that led to the world that maybe we still live in. ${ }^{74}$ Put differently, those concepts and values informed the basic structures that supported the construction and working of the political entities and regimes that really existed then. ${ }^{75}$ These are, in short, the conceptions and values that encouraged the main rules of the game with which the various competing interests then faced each other and settled their differences. As can be seen, these rules and conceptions were very different from ours. Originally deployed at the height of the Middle Ages $-12^{\text {th }}$ and 13th centuries-, they would remain uncontested, practically and substantially, until the 18th, even though, today, we could identify in retrospect certain earlier theoretical elaborations (more or less developed) which only after that date, however, worked their way through and found a practical application. However, one should not be carried away by this genetic or genealogical perspective, a frequent cause, not only of anachronistic readings of the sources, but rather of applying a selection process to these (otherwise inevitable in the work of the historian) that tends to have the perverse effect of decontextualising these and

72. "panjudicial conception of government". Mannori, Luca. "Justicia y Administración entre Antiguo y Nuevo Régimen". Revista Jurídica de la Universidad Autónoma de Madrid, 15 (2007): 125-146: 135.

73. "judicial image of power". Mannori, Luca. Bernardo Sordi. Storia del diritto administrativo. RomeBari: Laterza, 2001: 38.

74. Excellent summaries with which to complete or correct if necessary what is presented here are offered by Garriga, Carlos. “Orden jurídico y poder político en el Antiguo Régimen”, Cádiz, 1812: la constitución jurisdiccional, Carlos Garriga, Marta Lorente, eds. Madrid: Centro de Estudios Políticos y Constitucionales, 2007: 43-72; Agüero, Alejandro. "Las categorías básicas de la cultura jurisdiccional". Cuadernos de derecho judicial (2006) 6: 19-58; Costa, Pietro. "Il diritto nell'Europa moderna: strumenti e strategie", L'etá moderna (secoli XVI-XVIII): Culture, religioni, saperi, Roberto Bizzocchi, ed. (Storia Política e del Mediterraneo, Alessandro Barbero, dir., vol. 11). Rome: Salerno Editrice, 201 1: 415-456; Vallejo, Jesús. "El príncipe ante el derecho...".

75. For all, see Benedictis, Angela de. Politica, governo e istituzioni nell'Europa moderna. Bologna: Il Mulino, 2001 . 
thus depriving them of their own logic. As far as genesis is concerned, it is only that of the sources themselves that must not be evaded for a correct and more fertile understanding.

However, whereas those rules of the game were not challenged until the date indicated and their liquidation was the result of revolutionary processes generally not free from violence, their application did not occur pacifically and smoothly either. Indeed, their own validity was always subject to confrontation with practices that were, in principle, alien, and the way of dealing with war provides a good example of this. Let us see this quickly and succinctly.

\section{War}

In the penultimate decade of the $14^{\text {th }}$ century, the canonist Honorat Bovet wrote his famous Arbre des batailles, a work that has been called una auténtica enciclopedia de la caballería, ${ }^{76}$ and also a verdadero compendio del arte de la guerra and -what interests us more here- an auténtico tratado sobre derecho bélico. ${ }^{77}$ A Doctor in Decrees from the University of Avignon and prior of a small Benedictine establishment in Selonnet, in Upper Provence, Bovet is not thought of, however, as someone dedicated to studies and the contemplative life. His desire to intervene in the political and religious affairs surrounding the Western Schism is not only behind his works, but also seems to have led him to be an active member of Charles VI's close circle; it is to King Charles that the Arbre is dedicated. The fact that today almost a hundred manuscript copies have survived and that the work was the subject of nine printed editions between 1477 and 1515 gives an idea of its extraordinary spread. Written in the vernacular and soon translated into other vernacular languages, it can be said that it was a work of dissemination of doctrine on war as it had crystallized in the first phase of maturity of the ius commune. The imprint of Bartolo da Sassoferrato and Giovanni da Legnano (the author of the first real de bello treatise barely thirty years earlier) can easily be traced in Bovet's work. Habitually found in noble libraries all over Europe, in Castile, just before the mid $14^{\text {th }}$ century, Íñigo López de Mendoza and Álvaro de Luna did not hesitate to agree on one thing: to commission translations of a book tan leido por los caballeros como una autoridad sobre las leyes de la guerra. ${ }^{78}$ In one of these

76. “an authentic encyclopaedia of chivalry", Gómez Moreno, Ángel. "La militia clásica y la caballería medieval: las lecturas de re militari entre Medievo y Renacimiento". Evphrosyne: Revista de Filologia Clássica, 23 (1995): 83-97: 96.

77. "true compendium of the art of war"; "authentic treatise on the law of armed conflict". For both remarks: Contreras, Antonio. "Estudio introductorio" Honoré de Bouvet, Árbol de batallas: versión castellana atribuida a Diego de Valera, ed. Antonio Contreras. Madrid: Ministerio de Defensa, 2008: 1329. The attribution of this Spanish translation to Diego de Valera is dubious. Against this opinion, for example: Velasco, Jesús R. El debate sobre la caballería en el siglo XV: la tratadística caballeresca castellana en su marco europeo. Valladolid: Junta de Castilla y León, 1996: 116-119, 221-222, 392-393.

78. "So widely read by knights as an authority on the laws of war". Keen, Maurice. La caballería. Barcelona: Ariel, 1986: 308. For this, simply refer also to: Biu, Hélène. La traduction occitane de l'Arbre 
translations, the one commissioned by the Constable of Castile, we can read the following under the heading "Si otro príncipe qu'el Enperador puede ordenar guerra":

Aquí conviene que sepamos si los otros príncipes pueden mandar hazer guerra. E yo vos respondo que sí, según derecho; mas otra presona no puede mandar hazer guerra. E la razón es que non pueden ni deve ninguno traer armas sin licencia del principe. E ay otra razón, que ninguno no puede ni deve tomar derecho de otro si le á hecho tuerto; mas conviene qu'el principe le haga justicia. Mas el día de oy cada uno manda hazer guerra, lo cual de derecho hazer no se deve.79

The text clearly expresses the growing restriction of the concept of war that would be imposed on a culture modelled by the European ius commune. Only the prince, the individual or collective person that holds the maximum iurisdictio and does not acknowledge a higher instance, can declare war; therefore, one can only speak authoritatively of wars when they are declared and led by the prince.

That said, liable to contradiction and with its application subject to a jurisprudential (not legal) regime, that doctrine, in the end an opinion, but a qualified one, extracting all its authority and normative force from endless exegesis and commentary of revered texts as well as from the degree of consensus about them, would not be entirely peaceful until the late 16th century, in a context torn by the wars of religion. ${ }^{80}$ And the attitude of the jurists had an exact parallel among the theologians. While, in his famous formula about the three requisites a war had to comply with to be considered just, Thomas Aquinas had reserved the first place for the auctoritas principis, so that the potestas bellandi only corresponded licitly to him, ${ }^{81}$ nearly three centuries later, Francisco de Vitoria, after developing a wider and more inclusive concept of war than Aquinas', where the prince had exclusive

des batailles de Honorat Bovet. Paris: École Nationale de Chartes (PhD Dissertation), $2000<$ http:// theses.enc.sorbonne.fr/2000/biu>; Álvarez, M. Carmen. “La biblioteca de Don Fadrique Enríquez de Ribera, I Marqués de Tarifa (1532)". Historia. Instituciones. Documentos, 13 (1986): 1-40; Çeçen, Zeynep K. Interpreting Warfare and Knighthood in Late Medieval France: Writers and their Sources in the Reign of King Charles VI (1380-1422). Ankara: Bilkent University (PhD Dissertation), 2012 <http://www.academia. edu/2104902>; Taylor, Craig. Chivalry and the Ideals of Knighthood in France during the Hundred Years War. Cambridge (UK): Cambridge University Press, 2013.

79. "Here it is worth us knowing if the other princes can order war to be made. And I answer you that yes, according to law; no other person can order war to be made. And the reason is that they cannot nor should not carry arms without permission of the prince. And there is another reason, that no-one can nor should take revenge against he who injures him, but it is necessary for the prince to impose justice. Currently, every one wages war against everyone else, which is against the law and must not be done." Árbol de batallas: versión castellana...: 86.

80. Haggenmacher, Peter. Grotius et la doctrine de la guerre juste. Paris: Presses Universitaires de France, 1983: 134 and following. See also Quaglioni, Diego. “Pour une histoire du droit de guerre au début de l'âge moderne: Bodin, Gentili, Grotius". Laboratoire italien, 10 (2010): 27-43 (with an Italian version in Teatri di guerra: rappresentazioni e discorsi tra età moderna ed età contemporanea, Angela De Benedictis, Clizia Magoni, eds. Bologna: Bononia University Press, 2010: 29-42), emphasising how war will continue to be thought of in legal terms and assimilating it to a legal process, in perfect consonance with the way of understanding political power essentially as iurisdictio.

81. Haggenmacher, Peter. Grotius et la doctrine...: 122 and following; Russell, Frederick H. The Just War in the Middle Ages. Cambridge (UK): Cambridge University Press, 1975: 267 and following. 
rights only to a war of aggression (since the prince is the legitimate holder of an authority that resides in the communitas or respublica perfecta he presides over), still elaborates with numerous examples for the sake of clarity:

\begin{abstract}
Ex quibus sequitur, quod alii reguli seu principes, qui non praesunt rei publicae, non possunt bellum inferre aut gerere, quemadmodum dux Albanus aut comes Beneventanus. Sunt enim partes regni Castellae et per consequens non habent perfectas res publicas, sed truncatas. Sed est notandum, quod cum haec sint magna ex parte aut iure gentium aut humano, consuetudo potest dare facultatem belli gerendi. Unde si quae civitas aut princeps obtinuit antiqua consuetudine ius gerendi per se bellum, non est ei neganda haec auctoritas, etiam si alias non esset res publica perfecta. Item etiam necessitas hanc licentiam et auctoritatem concedere posset. ${ }^{82}$
\end{abstract}

Hardly a decade after the death of Thomas Aquinas and culminating what could be called the purposeful movement to develop coutumiers that arose in France during the $13^{\text {th }}$ century, Philippe de Beaumanoir wrote Li livres des coustumes et des usages de Beauvoisins, ${ }^{83}$ whose chapter LIX was dedicated precisely to wars, comment guerre se fet et comment guerre faut, in reality a compilation of the customary rules that covered the droit de guerre recognised to the gentius hommes, i.e. the nobles, car autre que gentil homme ne pueent guerroier. ${ }^{84}$ Even with this restriction, the contrast with the position of Doctor Angelicus could not be clearer, and the difference was in the custom, the same factor that, two and a half centuries later, was enough for Francisco de Vitoria to consider the resort to war by the initiative of the non-sovereign civitas aut princeps licit. ${ }^{85}$ Although a theologian, Vitoria did not restrict his choice of authorities, and like other specialists in his field, he appealed to the Fathers of the Church and the Philosopher together with such other renowned jurists as Bartolus and Panormitanus in his argumentation about what authority was competent to declare and wage war, an argumentation headed by a quotation from the Digest. Indeed, in the culture forged by these jurists, custom was not below the law ${ }^{86}$; both were regarded as the revelation of an identical, unalterable order.

82. Vitoria, Francisco de. De iure belli, Carlo Galli, ed. Rome-Bari: Laterza, 2005: 24 (II, 3).

83. Beaumanoir, Philippe de. Coutumes de Beauvaisis, ed. Amédée Salmon, Paris: Picard, 1899. A comparative approach to the Coutumes in Miller, Samuel J.T. "The Position of the King in Bracton and Beaumanoir". Speculum, $31 / 2$ (1956): 263-296; and biographically in Lécuyer, Sylvie. "Un idéal social, politique et religieux transmis de père en fils: du roman de Jehan et Blonde aux Coutumes de Beauvaisis". Revue des Langues Romanes, 1 (2000): 129-142.

84. "How the war is done and how it must be done", "the law of war", "only knights and nobles can wage war". Beaumanoir, Philippe de. Coutumes de Beauvaisis...: II, 357. See also the contemporary episode, offered as an example in Bordier, Henri Léonard. Philippe de Remi, sire de Beaumanoir, jurisconsulte et poëte national du Beauvaisis, 1246-1296. Paris: Librairie Techener, 1869: 81-93.

85. The idea of sovereignty must be understood here in the only sense for that time: the person who held it was exempt from the judgment of another, that is, not subject to a higher iurisdictio. Costa, Pietro. "La soberanía en la cultura político-jurídica medieval: imágenes y teorías". Res publica, 17 (2007): 33-58. 86. Petit, Carlos; Vallejo, Jesús. “La categoria giuridica”...: 748-749; and with more technical forcefulness: Vallejo, Jesús. Ruda equidad, ley consumada... 
Mas el día de oy cada uno manda hazer guerra, lo cual de derecho hazer no se deve. ${ }^{87}$ Remember that this is how the fragment of the Árbol de batallas mentioned above ended. Honorat Bovet undoubtedly tacitly left there his testimony about the wars that ravaged Provence after the death of Queen Joanna of Naples in 1382. It is a shame that nowadays we have no critical edition of the Arbre, as it would also be worth comparing the text of the Castilian translation we have been dealing with (A) with the French. Let us do so anyway with the two version of the latter: the only existing modern edition, already long in the tooth and based on a manuscript from 1456 from the Royal Library of Belgium ${ }^{88}$ (B), and an incunable form from 1493 kept in the National Library of France ${ }^{89}(\mathrm{C})$ :

A.
Si otro príncipe qu'el Enperador
puede ordenar guerra.
Aquí conviene que sepamos si los
otros príncipes pueden mandar
hazer guerra. E yo vos respondo
que sí, según derecho; mas otra
presona no puede mandar hazer
guerra. E la razón es que non
pueden ni deve ninguno traer
armas sin licencia del príncipe.
E ay otra razón, que ninguno
no puede ni deve tomar derecho
de otro si le á hecho tuerto; mas
conviene qu'el príncipe le haga
justicia. Mas el día de oy cada
uno manda hazer guerra, lo cual
de derecho hazer no se deve.

de derecho hazer no se deve.

\section{B.}

Se ung altre prince que l'empereur peut ordonner guerre.

Puisque je vous ay dit et moustré comment l'empereur peut ordonner et commander guerre, maintenant nous convient il sçavoir comment ainsi le feront les aultres princes cèst a dire se ils pourront ordonner guerre. A quoy je vous respons que ouy selon droit, car le conseil de faire guerre est devers les princes, ainsi que dient les loix, mais selon la verité, aultre personne qui ne soit prince ne peut commander guerre generale. Et la raison si est, car nuls ne doit ne ne peut porter armes sans la licence du prince. Et aussi selon l'aultre raison ung homme ne peut pas de soy mesme prendre de faire droit de ung aultre se tort lui tient, mais il est necessaire que le prince fasse justice entre ses hommes. Toutefois aujourd'huy chascun veult commander guerre et mesme ung simple chevalier contre ung aultre. Ce que faire ne se doit selon les droits.
C.

Se aultre prince que lempereur peut ordonner ne commander guerre.

Presce que je vous ay dit comment lempereur peut ordonner guerre, nous convient il scavoir se le feront les autres seigneurs, cest a scavoir, silz pourront ordonner guerre. Je vous dy que ouy selon droit, car le conseil de faire guerre est par devers les seigneurs se dient les drois. Mais selon verite aultre personne qui ne soit prince ne peut commander guerre generalle. Et ceste est la raison: car nul ne peut ne doit porter armes sans la licence des princes. La seconde raison est car vng homme ne peut pas prandre droit de vng autre se tort il lui tient, mais comment (sic) que le prince face iustice entre ses hommes. Touttefois au iourduy chescun veult commander guerre, mesmement vng chevalier contre vng autre, ce que faire ne se doit selon les drois.

87. "Currently, every one wages war against others, which is against the law and must not be done". 88. L'arbre des batailles d'Honoré Bonet, ed. Ernest Nys. Bruselas: C. Muquardt, 1883: 90-91.

89. Bonet, Honorat (Honoré Bouvet). L'arbre des batailles. Paris: Antoine Vérard, 1493 <http://gallica.bnf. fr/ark:/12148/btvlb7300069m>. 
As can be seen, the Castilian translation obscures the precise reason Bovet's initially affirmative answer to the question was based on. Princes other than the emperor can order and wage war, because "le conseil de faire guerre" belongs to them by law. At this point, the incunable used the more general term "seigneurs", avoiding the ambiguity in the use of "prince" and thus establishing more clearly what, in contrast, is reserved solely for the prince, that is, the "guerre generale". However, the Castilian version also eludes this precision. Was this simple economy in the translation or a deliberate political option?

We can resort to yet another comparison, this time with a Catalan translation of 1429, and thus, earlier than the Castilian and whose manuscript is also in the Bibliothèque Nationale de France:

\begin{abstract}
Apres que vous he dit com lemperador pot ordonar e començar guerra nos coue saber com ho faran los altres princeps, co es a dir, a dir si ells poden ordonar guerra, e dits vos que hoc, segons dret. Car lo conseil de fer guerra es ab los princeps, ço diu lo dret. Mas segons dret altra persona que no sia princep no pot ordonar guerra general. E aço es la raho: car nengun no deu portar armes ses licencia del princep segons les leys. Laltra raho si es car vn hom no pot pendre dret de un altre si li te tort, mas fa que lo princep fara justicia entre aquestes. Tota vegada, al jorn de huy tot hom vol comandar guerra, hoc un simple cavaller contra vn altre, ço que pas nos deu fer segons los drets. ${ }^{90}$
\end{abstract}

As we see, the Castilian version is resolutely abbreviated and, in this sense, less true to an archetype which both the earlier and later versions appear to be closer and better adjusted to. Naturally, the result of the operation is far from being innocuous, although we cannot take this conclusion any further now without entering into the realm of conjecture.

In any case, what is shown as evidence is that the restrictive position held by Bovet regarding the right of war did not reflect the rather antagonistic reality that surrounded him. He left both things clear at the end of his argument. We now know that his posture, far from being unanimously accepted, even among theologians and jurists, would take time to impose itself. And in recent decades, historians have continued to pay redoubled attention to the violent outbreaks of the multiple forms of feud, the inimicitia, significantly persistent throughout the Middle Ages and a good part of the Early Modern period which would confirm all of the above through action - unless, of course, one teleologically refuses to see in it anything

\footnotetext{
90. "Given that I comment to you that the emperor can order to start the war, we must know how the other princes can do it, that is, if they can order the war to start, and the answer is so, according to the law, because the law says that the advice to wage war belongs to the princes. According to the law only the princes can order general war. The reason is that no one can take arms without licence from the prince, according to the law. Another reason is that no one can avenge the injuries from other person and only the prince can impose justice among them. Anyway, nowadays anyone wishing to command war, even a simple knight against another, although this is not allowed according to the law." Bibliothèque nationale de France. MSS Espagnol, 206 <http://gallica.bnf.fr/ark:/12148/btvlb8436401j/ fl.image>: “Aquest libre ha fet tralladar lo honorable mossen Ramon de Caldes en lany mil CCCC XXIX, lo qual ha escrit Loren Rexarch...".
} 
more than a residue from the past and a factual liability for the future. ${ }^{91}$ Fehden in Franconia, ${ }^{92}$ seigneurial guerrae in Languedoc, ${ }^{93}$ inimicitiae between lineages in Siena $^{94}$ and fights between fazioni in the Duchy of Milan ${ }^{95}$ or between bandos in Basque lands, ${ }^{96}$ also bandositats in the kingdom of Valencia ${ }^{97}$ or aristocratic feuds in England, ${ }^{98}$ to cite only a few examples from recent publications, show, beyond the indubitable local peculiarities, the strength and general nature of the phenomenon of the noble feud between the $13^{\text {th }}$ and $16^{\text {th }}$ centuries. It can be said, therefore, that the feud constituted one of these "frames and forms and patterns in which politics took place" that John Watts designates (always susceptible to being adapted and manipulated) as structures, "the basic currencies in which later medieval politics were conducted", a structure moreover "that received contemporary recognition", as those the English historian believes should be given priority in the analysis. ${ }^{99}$

91. For an overview of the literature produced in this field by the historiography from the Anglo-German
area, see Feud in Medieval and Early Modern Europe, Jeppe B. Netterstrøm, Bjørn Poulsen, eds. Aarhus:
Aarhus University Press, 2007. But one should not neglect the contribution of Italian historiography, of
which we should mention at least: Zorzi, Andrea. "Ius erat in armis: faide e conflitti tra pratiche sociali
e pratiche di governo", Origini dello Stato: processi di formazione statale in Italia fra medioevo ed età moderna,
Giorgio Chittolini, Anthony Molho, Pierangelo Schiera, eds. Bologna: Il Mulino, 1994: 609-629; Zorzi,
Andrea. "I conflitti nell'Italia comunale: riflessioni sullo stato degli studi e sulle prospettive di ricerca",
Conflitti, paci e vendette nell'Italia comunale, Andrea Zorzi, ed. Florence: Firenze University Press, 2009 :
7-41. Published too late to review here is also Povolo, Claudio. "Faida e vendetta tra consuetudini e
riti processuali". Storica, 56-57 (2013): 53-103, with an English version in "Feud and vendetta: customs
and trial rites in Medieval and Modern Europe. A legal-anthropological approach". Acta Historiae, 23/2
(2015): 195-244. 92. Zmora, Hillay. The Feud in Early Modern Germany. Cambridge (UK): Cambridge University Press, 2011 , and the summary dedicated to this by Stuart Carroll in: H-HRE, H-Net Reviews, October $2012<$ http:// www.h-net.org/reviews/showrev.php?id=35932>.

93. Firnhaber-Baker, Justine. "Seigneurial War and Royal Power in Later Medieval Southern France". Past and Present, 208 (2010): 37-76.

94. Théry, Julien. "Faide nobiliaire et justice inquisitoire de la papauté à Sienne au temps des Neuf: les recollectiones d'une enquête de Benoît XII contre l'évêque Donosdeo de' Malavolti (ASV. Collectoriae, 61A and 404 ${ }^{\mathrm{a}}$ )", Als die Welt in die Akten kam: Prozeßschriftgut im europäischen Mittelalter, Susanne Lepsius, Thomas Wetzstein, eds. Frankfurt am Main: Vittorio Klostermann, 2008: 275-345.

95. Gentile, Marco. Fazioni al governo: politica e sicietà a Parma nel Quattrocento. Rome: Viella, 2009.

96. Fernández de Larrea, Jon Andoni. “Las guerras privadas: el ejemplo de los bandos oñacino y gamboíno en el País Vasco". Clio $\theta$ Crimen, 6 (2009): 85-109; Urizar, Hiart. "Las guerras de bandos en Markina: una aproximación". Vasconia, 38 (2012): 41-66.

97. Ponsoda, Santiago; Soler, Juan Leonardo. "Violencia nobiliaria en el sur del reino de Valencia a finales de la Edad Media". Anales de la Universidad de Alicante: Historia Medieval, 16 (2009-2010): $319-347$. 98. Kaminsky, Howard. "The Noble Feud in the Later Middle Ages". Past and Present, 177 (2002): 55-83; Armstrong, Jackson W. "Violence and Peacemaking in the English Marches towards Scotland, c.14251440", The Fifteenth Century 6: Identity and Insurgency in the Late Middle Ages, Linda Clark, ed. Woodbridge: The Boydell Press, 2006: 53-72.

99. Watts, John. The Making of Polities...: 34-42; Meanwhile, Stuart Carroll. Blood and Violence in Early Modern France. Oxford: Oxford University Press, 2006: 7, states that, "Feuding was integral to the conduct of politics in early modern France because it was one of the key forms of competition for power, a mechanism by which the struggle for dominance was played out. Nevertheless, when kings were able to satisfy the ambitions of the social elite, feuds did not result in disorder or high levels of bloodletting". 
Otherwise, there is no solution of continuity, as sometimes professed, ${ }^{100}$ between feud and war. Qualitatively speaking, the former is an eventual manifestation of the latter in the same sense we now habitually give to war as a circumstantial manifestation of international relations. Of course, the word feud, of Germanic origin, as is war, is an infrequent term in the sources, if not completely absent in those from after the $13^{\text {th }}$ century except for the case of the German fehde. However, I believe that it is less equivocal than the expression "private war", or serves better to avoid precisely the ambiguity that results from the use of that expression, behind which lies an undoubtedly modern idea about war that associates it uniquely and by definition with the State. Indeed, in the culture of European ius commune, not only was there the notion of the distinction between public and private, but this distinction was fundamental precisely in the conceptualisation of political power, in other words, of iurisdictio. This has been defined since the time of the glossa and without substantial changes in later centuries, as potestas de publico introducta cum necessitate iuris dicendi aequitatisque statuendae. ${ }^{101}$ It is a different thing, however, whether this translated into something more than the defining of iurisdictio regarding what was beyond its reach by being confined to the private households, as the jurists of the ius commune, even with a basis and materials suitable for this, showed no interest or provision, as is known, in organising the materia iuris in public law, on the one hand, and private law, on the other. ${ }^{102}$ Among other reasons, it is precisely this ingrained reluctance which, deployed before the question of whether ha senso chiedersi se la faida fosse un regolamento di conti privato o un 'conflitto internazionale'?, led Stefano Mannoni to respond, no, con tutta probabilità e, se propio si vuole, allo stadio finora raggiunto dalla storiografia. ${ }^{103}$

Actually, if it did not sound too emphatic and even somewhat solemn, one could say that in the beginning everything was feud; with its privileges, which it had, the king's wars included. ${ }^{104}$ Or, if you prefer, war was any alteration, any disturbance of the peace, any form of conflict resolved by resorting to the force of arms. Such a disorder could occur with varying repercussions involving a greater or smaller number of individuals, but conceptually there was no difference. And this

100. More among anthropologists than historians. Notterstrøm, Jeppe Büchert. "Introduction: The Study of Feud in Medieval and Early Modern History", Feud in Medieval and Early Modern Europe: Jeppe Bückert Netterstrøn; Bjørn Poulsen, eds. Aarhus: Aarhus University Press, 2007: 46-48.

101. See Vallejo, Jesús. Ruda equidad...: 40-49.

102. Chevrier, Georges. “Remarques sur l'introduction et les vicissitudes de la distinction du 'jus privatum' et du 'jus publicum' dans les oeuvres des anciens juristes français". Archives de philosophie $d u$ droit, 1 (1952): 5-77. On the importance of the question in the political order and the way it affects the historiographic practice, Schaub, Jean-Frédéric. "El pasado republicano del espacio público", Los espacios públicos en Iberoamérica: ambigüedades y problemas: siglos XVIII-XIX, François-Xavier Guerra, Annick Lempérière, eds. Mexico: Fondo de Cultura Económica, 1998: 27-53.

103. "there is any sense asking whether the feud was a private settling of scores or an 'international conflict'?", "no, not in all probability and in the current state of historiography if you like". Mannoni, Stefano. "Relazioni internazionali", Lo Stato moderno in Europa: istituzioni e diritto, Maurizio Fioravanti, ed. Rome-Bari: Laterza: 2002: 206-229: 208.

104. Haggenmacher, Peter. Grotius et la doctrine...: 76 and following. 
identification of such a wide and diverse range of events with war would last long, as Merio Scattola was able to see:

\begin{abstract}
Ancora nel Seicento gli autori politici continuano a chiedersi come debbano essere interpretate le diverse forme di conflitto e rispondono che guerra è lo scontro tra autorità pubbliche, ma è anche il contrasto tra privati oppure quello misto tra persone private e persone pubbliche. Guerra è in primo luogo il duello, ma guerra sono allo stesso tempo anche le repressaliae, le faide tra casati nobili, tra città o tra altre forme di potestà, come guerra è la 'legittima difesa' del magistrato inferiore contro i comandi iniqui del re e l'autodifesa del privato assalito da un predone, fosse costui anche l'imperatore in persona, quando la pubblica autorità non può intervenire in tempo. ${ }^{105}$
\end{abstract}

In line, as we saw, with a reasoning that was both topical and casuistic, not axiomatic, and prudential, not epistemic, jurists and theologians ${ }^{106}$ dispensed with a prior definition, a pre-stablished concept, of therefore a strict and fixed delimitation of what war is. This is simply part of the phenomenology of the conflict, which is in turn intrinsic to the social reality and does not constitute, in that mode of reasoning, a subject of theory, but rather a matter to examine from the varied and changing experience, in response to the specific and substantive issues that arise from each case related with justice and morality, with the order of law and that of theology. Hence, the reflection on war did not constitute an autonomous body of knowledge, a self-sufficient subject, but instead became a tradition of thought on just war, that is, about the conditions war must meet to avoid clashing with the principles and values that the aforementioned disciplines had it in their charge to rule.

However, the practice of war broadly understood as feud, which envisaged and also included formulas and specific rites of achievement and restoration of peace as a corollary, is much earlier than the intellectual tradition - starting not before the $12^{\text {th }}$ century- of just war, although much the configuration of the latter certainly used materials that were just as old. ${ }^{107}$ We have already referred above to a whole historiography effectively focussed on the study of conflicts, their warlike manifestations and the extrajudicial mechanisms for resolving them in the immediately post-Carolingian centuries, a period that has been considered l'âge d'or de la faide. ${ }^{108}$ How then did the architects and those who generally accepted the just

105. "Still in the 17th century, the political authors continued asking themselves how the diverse forms of conflict should be interpreted, and they answered that war is the clash between public powers, but also the discord between individuals, or of a mixed nature between private and public people. In first place war is the duel, plus war is at the same time and equally the represaliae, the faide between noble lineages, between cities or between other forms of power, as war is the 'legitimate defence' of the lower magistrate against the king's wicked commands and the self-defence of the individual attacked by a robber, although this be the emperor in person, when the public authority fails to intervene in time". Scattola, Merio. "Introduzione", Figure della guerra: la riflessione su pace, conflitto e giustizia tra Medioevo e prima età moderna, Merio Scattola, ed. Milan: Franco Angeli, 2003: 16-17.

106. Villey, Michel. Questions de Saint Thomas sur le droit et la politique. Paris: Presses Universitaires de France, 1987.

107. Haggenmacher, Peter. Grotius et la doctrine...: 11 and following.

108. "the golden age of feud". Haggenmacher, Peter. Grotius et la doctrine...: 81. 
war tradition doctrinally and practically face the widespread and enduring reality of feud after that time, as we have also had occasion to note?

There were two traits of mentality and culture that sustained the feud. In the first place, there was the idea that we speak disapprovingly of nowadays, namely "taking justice into one's own hands". This, however, was an idea and a practice that, under certain circumstances, basically which allowed one to invoke legitimate defence, could be accepted and accommodated by scholastic culture and particularly by its legal expression, the ius commune, especially because the latter will always regard the resort to war as an exsecutio iuris, all the more legitimate when it was somebody endowed with iurisdictio - thus a public entity - who enacted this and put it into effect $^{109}$. It is true that from the $13^{\text {th }}$ century, in the most urbanised regions of Europe, other developments and thus other values were moving slowly in the opposite direction. Without leaving the subject of law, the increased scope for initiative for a judge in the procedural sphere, which would allow him to act inquisitorially ex officio, will then be at the starting point of a change of direction in the history of penal justice with undeniable consequences for the element of revenge inherent to the feud. ${ }^{110}$ That enlarged capacity of intervention by the judge (in other words, by a political power) will unhesitatingly be justified formally by invoking custom, not the law, and the novel principle on the merits that offence does not just harm its victim but also the civitas or communitas (since it infringes the pax publica). This is a good example of the not always concurrent, but often contradictory, tendencies that could arise within the ius commune and that, after all, reflected those of the same nature in the social reality that the law attempted to regulate. At the same time, discourses proliferating since the $13^{\text {th }}$ century extolling the value of peace as a foundation of social order - at times voiced as movements for peace-keeping, as seen especially in Italian cities - also targeted the practice of vendetta. Nevertheless, as Andrea Zorzi aptly remarks in this respect, $i$ valori del discorso politico non erano neutri, ma appartenevano a un registro variabile declinato nel vivo del conflitto politico, 111 which cautions against drawing an absolute and generalized antithesis between peace-extolling discourses on one hand, and the practice of revenge on the other.

In fact, far from being incompatible with, or unrelated to, the feud, peace was the other side of the coin, its second trait of cultural identity. This peace was, however, understood as the maintenance and continuous renovation of an order and a

109. Quaglioni, Diego. "Le ragioni della guerra e della pace", Pace e guerra nel basso medioevo: atti del XL Convegno storico internazionale (Todi, oct. 2003). Spoleto: Fondazione Centro Italiano di Studi Sull'Alto. Medio Evo, 2004: 113-129; Quaglioni, Diego. "Pour une histoire du droit de guerre...".

110. Sbriccoli, Mario. “Vidi communiter observari: l'emmersione di un ordine penale pubblico nelle città italiane del secolo XIII". Quaderni fiorentini per la storia del pensiero giuridico moderno, 27 (1998): 232-268.

111. "the values of political discourse were anything but neutral, they were incorporated into a changing register that adapted itself to each occasion of political conflict". Zorzi, Andrea. "Fracta est civitas magna in tres partes: conflitto e costituzione nell'Italia comunale". Scienza $\theta$ Politica, 39 (2008): 61-87: 68. On the proliferation of the motif of peace in sermons and political discourses: Prêcher la paix et discipliner la société: Italie, France, Angleterre (XIII $-X V^{e}$ siècles), Rosa Maria Dessi, ed. Turnhout: Brepols, 2005; Offenstadt, Nicolas. Faire la paix au Moyen Âge: discours et gestes de paix pendant la guerre de Cent Ans. Paris: Odile Jacob, 2007. 
balance considered natural rather than the mere absence of war. The same was true for a peace, not imposed, but achieved through mutual compensation and entrusted with the permanent threat of war, but also pacts and negotiation. In this respect, European ius commune did not lack the capacity to integrate the feud, as it shared the presupposition of the existence of an immutable natural order that reached the social reality and that had to be safeguarded at any cost, as it was identified with justice itself. However, the development of this law would also open the path for a distinct way of achieving this target that would end up prevailing and would continue to have consequences in relation with war, the notion of this and its practice. To use a fortunate and expressive formula, this was the way that led from a negotiated, communal and restorative justice to another hegemonic or bureaucratic and of a punitive character. ${ }^{12}$ Or, in another no less intuitively revealing statement, from a peace-centered order to public order. ${ }^{113}$ Shortly after 1750 , one could read Crimen fractae pacis publicae constituunt etiam diffidationes, seu bella priuatorum in a manual of what we would nowadays call penal law, whose author still did not forget the contrast that this represented with earlier times explicitly referred to as prior to the 1600s, as those wars, that could no longer called as such without specifying, olim, $v i$ iuris manuarii, omnibus, summis et imis permissa, quia ius belli gerendi tunc temporis non erat regale, $v t$ hodie. ${ }^{114}$ There was talk in this step of crimes contra securitatem et vtilitatem publicam and the manual was German, but, in general lines, the diagnosis was valid for all Europe.

The aforesaid novelties and changes of orientation, some hardly insinuated in the $13^{\text {th }}$ century, would take centuries to assert themselves and displace or subordinate earlier ideas and uses, so many that, even without going beyond the corresponding chronological limits of the validity of the ius commune, only from an exaggeratedly teleological perspective can one ignore or relegate such ideas and uses in order to explain the late medieval and early modern centuries. There is no lack of arguments to sustain that the assembly of all the components of what is commonly known as the doctrine of just war did not really come about until around $1500 .{ }^{115}$ We know that one of these pieces, the one that reserved the exclusive right to wage war to the sovereign prince, would not garner general adhesion until the end of the $16^{\text {th }}$ century. Under these conditions, the two above-mentioned characteristic aspects of

\footnotetext{
112. Sbriccoli, Mario. “Giustizia negoziata, giustizia egemonica: riflessioni su una nueva fase degli studi di storia della giustizia criminale", Criminalità e giustizia in Germania e in Italia: pratiche giudiziarie e linguaggi giuridici tra tardo medioevo ed età moderna, Marco Bellabarba, Gerd Schwerhoff, Andrea Zorzi, eds. Bologna: Il Mulino, 2001: 345-364; Sbriccoli, Mario. "Giustizia criminale", Lo Stato moderno in Europa...: 163-205.

113. Povolo, Claudio. "Dall'ordine della pace all'ordine pubblico: uno sguardo da Venezia e il suo stato territoriale (secoli XVI-XVIII)", Processo e difesa penale in età moderna: Venezia e il suo stato territoriale, Claudio Povolo, ed. Bologna: Il Mulino, 2007; 15-107.

114. Meister, Christian Georg Friedrich. Principia iuris criminalis Germaniae communis. Göttingen: Victorino Bossiegel, 1780: 242. The first edition dates from 1755.

115. Johnson, James Turner. Ideology, Reason, and the Limitation of War: Religious and Secular Concepts, 1200 1740. Princeton: Princeton University Press, 1975: 8.
} 
the feud, not foreign to the protean and versatile system of ius commune, ${ }^{116}$ would still enjoy long vitality. A deeply-rooted culture of revenge, not at all irreconcilable with caritas $^{117}$ nor always with misericordia ${ }^{118}$, could continue to be deployed after the $13^{\text {th }}$ century, a culture nowadays increasingly dealt with and better known to historians. ${ }^{119}$ The two modes of justice mentioned, the negotiated justice and official justice, far from being mutually exclusive and the latter replacing the former without further ado, would intertwine in such a way that one could talk about an authentic osmosis between the two throughout the Ancien Régime, which led Mario Sbriccoli to conclude:

L'attitudine negoziale e l'idea della ritorsione verranno bandite dal campo penale soltanto con l'arrivo della codificazione, dopo la svolta epocale originata dalla Rivoluzione francese: ma anche l'assolutismo dei codici dovrà fare i conti con la lunga durata e adattare il suo passo a quello, ben più lento, della cultura dei popoli e delle persone. ${ }^{120}$

In fact, the parties in the judicial process used this on more than a few occasions to perfect a prior agreement, not to show the impossibility of reaching it, or as an instrument of pressure during a negotiation. ${ }^{121}$ These were strategies that not only displayed the initial preference of the social actors for the more traditional and less dramatic or theatrical forms of justice ${ }^{122}$ —and surely also less expensive-, but also equally the validity, as we have seen, of the ideological principal of subordination

116. Claudio Povolo wrote: Il complessivo discorso giuridico conosciuto come diritto comune, lungi dall'attestare l'affermazione di una giustizia espressione egemonica della state law, era funzionale al mantenimento di quel sistema giuridico comunitario, caratterizzato da un'innata vocazione compromissoria e dalla faida ("The global legal discourse known as diritto comune, far from witnessing the affirmation of justice that expressed the hegemony of state law, was funtional for the maintenance of that communal legal system characterised by an innate arbitration vocation and the feud". "Dall'ordine della pace...": No. 8). Meanwhile, Mario Sbriccoli spoke about "la logica anti-imperativistica del diritto comune" ("the anti-imperative logic of the ius commune") in "Giustizia criminale...": 170.

117. Throop, Susanna.A. Crusading as an Act of Vengeance, 1095-1216. Farnham: Ashgate, 2011.

118. Buc, Philippe. "Some Thoughts on the Christian Theology of Violence, Medieval and Modern, from the Middle Ages to the French Revolution". Rivista di Storia del Cristianesimo, 5/1 (2008): 9-28.

119. Vengeance in Medieval Europe: A Reader, Daniel Lord Smail, Kelly Gibson, eds. Toronto: University of Toronto Press, 2009; Hyams, Paul R. Rancor and Reconciliation in Medieval England. Ithaca: Cornell University Press, 2003; Vengeance in the Middle Ages: Emotion, Religion and Feud, Susanna A. Throop, Paul R. Hyams, eds. Farnham: Ashgate, 2010; Nassiet, Michel. La violence, une histoire sociale: France XVI ${ }^{e}$ XVIII ${ }^{e}$ siècles. Seyssel: Champ Vallon, 2011: maxime chapters 4 ("Vengeance et faide") and 9 ("La culture de vengeance dans les guerres de religion"); Carroll, Stuart. Martyrs and Murderers: The Guise Family and the Making of Europe. Oxford: Oxford University Press, 2009; Miller, William Ian. Eye for an eye. Cambridge (UK): Cambridge University Press, 2006.

120. "The negotiating attitude and the idea of retaliation would be banished from the criminal field only with the arrival of codification, after the change of epoch provoked by the French Revolution, but also the absolutism of the codes must settle with the long-term and adapt to the much slower speed of the culture of the peoples and individuals". Sbriccoli, Mario. "Giustizia criminale...": 172.

121. See the monographic issue on "Procedure di giustizia", Renata Ago, Simona Cerutti, eds. Quaderni storici, 101 (1999) 107-473.

122. On the penal process as a "theatre of power", Povolo, Claudio. “Dall'ordine della pace...": 15-107. 
of the iustitia to the caritas, that is, of the clearly subsidiary character of law with respect to religion. ${ }^{123}$ The judges shared this presupposition and encouraged the parties to reach agreements when the process was inevitable, while they did not hesitate to combine a repressive and exemplifying conception of punishment with a consideration of this as anche luogo e occasione per il recupero della dimensione 'negoziale' del giudizio, fondata sulla consuetudine, sull'equità, sulla misericordia. ${ }^{124}$

Moreover, the judicial sentences and decisions — which did not need to be motivated and did not cease to take the intuitus personae into consideration- were sometimes no more than an intermediate episode later exploited by the parties towards a negotiated end of the conflict, as has been lucidly shown recently for the numerous aristocratic clashes and wars that took place in the south of France during the $14^{\text {th }}$ century. ${ }^{125}$ Just as instrumental and inconclusive were the frequent royal decrees during those wars, restricting or prohibiting them. ${ }^{126}$ The role of the royal officials became more like that of real arbitrators and mediators according to their status - and not necessarily their position- whose actions, however, contributed resolutely to resolving those conflicts while also serving to increase the presence of the central power within the local and regional powers, more through their involvement in these commitments than through coercion. Something similar could have been claimed about the stati regionali italiani di epoca moderna, che solo con molta difficoltà riuscivano a garantire il mantenimento di un ordine pubblico costantemente minacciato dalle dinamiche fazionarie, and in which gli stessi giusdicenti locali si vedevano istituzionalmente investiti di funzioni più di tipo politico-mediatorie che di amministrazione della giustizia stricto sensu. ${ }^{127}$ The path towards the assertion of a "public penal law" from its first stirrings in the $13^{\text {th }}$ century was not short or easy, but rather a lunga e tormentata storia, again in the words of one of its most knowledgeable experts. ${ }^{128}$ The criminalisation of the feud and the consequent limitation of the right to and the concept of war was a chapter in this story, one that only concluded around 1600, not by chance coinciding with what historians consider the high point of the brigandage and banditry of the Ancien Régime, a phenomenon whose protagonists

123. See also Broggio, Paolo. "Linguaggio religioso e disciplinamento nobiliare: il "modo di ridurre a pace l'inimicitie private nella trattatistica di età barocca", I linguaggi del potere nell'età barocca 1. Politica e religione, Francesca Cantù, ed. Rome: Viella, 2009: 275-317.

124. "also the place and occasion for recovering the 'negotiable' dimension of the trial, based on custom, equity, misericordia". Sbriccoli, Mario. "Giustizia criminale...": 171. See also Alessi, Giorgia. Il processo penale: profilo storico. Rome-Bari: Laterza, 2007: 97 and following.

125. Firnhaber-Baker, Justine. "Jura in medio: the settlement of seigneurial disputes in later medieval Languedoc". French History, 26/4 (2012): 441-459.

126. Firnhaber-Baker, Justine. “Jura in medio...": 447-449; Firnhaber-Baker, Justine. "Seigneurial war and royal power...": 51-60.

127. "the Italian stati regionali from the early modern epoch, that only with great difficulty managed to maintain a public order constantly threatened by the factionary dynamics", "the self-same local judges found themselves institutionally invested with functions more of the political-mediating type than the administration of justice stricto sensu". Broggio, Paolo. "Linguaggio religioso e disciplinamento nobiliare...": 284 .

128. "long and tempestuous history", Sbriccoli, Mario. “Vidi communiter observari...": 254. 
in many cases, as has been shown, seem to have been more hijos de la faida antes que de la miseria. ${ }^{129}$ Nor is it plausible to attribute to chance that it was precisely in the $17^{\text {th }}$ century when historiography began to talk retrospectively and with reprobation of "private wars". ${ }^{130}$

Until then, language was also a battlefield. There were no relevant differences in either form or substance between wars by the princes and those undertaken by other lords (except for the obvious growing asymmetry of forces that ones and the others could mobilise). However, it has been shown that while those near the former carefully avoided calling the conflicts involving the latter "wars", the parties involved in these made open use of the word. ${ }^{131}$ It was another way of pushing reality along a path and in a precise direction, this time through resort to a selective use of language that not only aspired to describe the experience but also configure it in a specific sense. The resort that, as is known, Humpty Dumpty knew so well and Alice had the opportunity to test out. In the late Middle Ages and early modern period, rhetoric was all the more an important part of political action since the communis opinio forged by jurists (the principal source of civilis sapientia, and through which that political action must be legitimated) was not necessarily resolved, as we saw, by the existence of a single, indisputable view or decision. The same action could be conceptualised, for example, as rebellion or as resistance, understood as an offence deserving punishment or as the exercise of legitimate defence, addressed, in the end, as crimen laesae maiestatis or interpreted as a legitimate action by those habent iustam causam superioribus resistendi. ${ }^{132}$

129. "children of the feud rather than of misery". Torres, Xavier. "Faide e banditismo nella Catalogna dei secoli XVI e XVII", Banditismi mediterranei (secoli XVI-XVII), Francesco Manconi, ed. Rome: Carocci, 2003. See also Torres, Xavier. "Guerra privada y bandolerismo en la Cataluña del Barroco". Historia social, 1 (1988): 5-18; Povolo, Claudio. "La conflittualità nobiliare in Italia nella seconda metà del Cinquecento. Il caso della Repubblica di Venezia: alcune ipotesi e possibili interpretazioni". Atti dell'Istituto Veneto di Scienze, Letter e ed Arti, 151 (1992-1993): 89-139; Povolo, Claudio. "Retoriche giudizarie, dimensioni del penale e prassi processuale nella Repubblica di Venezia: da Lorenzo Priori ai pratici settecenteschi", L'amministrazione della giustizia penale nella Repubblica di Venezia (secoli XVI-XVIII), II: Retoriche, stereotipi, prassi, Claudio Povolo, Giovanni Chiodi, eds. Verona: Cierre Edizioni, 2004: 19-170.

130. Cange, Charles du Fresne du. "Des guerres privées et du droit de guerre par coutume", Glossarium mediae et infimae latinitatis. Graz: Akademische Druck-u. Verlagsanstalt, 1954: X, 100-108 (first edition in 1678). The expressions bellum publicum and bellum privatum can be found in the medieval doctrinal sources, the first much earlier and the second markedly later, from the $14^{\text {th }}$ century on, the latter surely introduced, after an isolated precedent in Summa by Thomas Aquinas, through the Romenising reflex of the jurists Haggenmacher, Peter. Grotius et la doctrine...: 83, 114 and following, also indicating the nonexistence of a relevant semantic distinction between bellum and guerra. The sources of the practice use the expression guerra publica to define the $14^{\text {th }}$-century seigniorial wars in Languedoc, while the antonymic expression never appears in these. Firnhaber-Baker, Justine. "Seineurial war...": 38 (note 4); Firnhaber-Baker, Justine. "Jura in medio...": 445. El Árbol de batallas, in the way of Giovanni da Legnano, in a passage contrasts guerra particular y general, see Árbol de batallas: versión castellana...: 125; L'arbre des batailles d'Honoré Bonet...: 229.

131. See Gamberini, Andrea. "Le parole della guerra nel ducato di Milano: un linguaggio cetuale", Linguaggi politici nell'Italia del Rinascimento, Andrea Gamberini, Giuseppe Petralia, eds. Rome: Viella, 2007: 445-467.

132. The latter sentence is from the Disquisitio prior iuridica with which the Italian cities defended themselves from Henry VII in 1313. Benedictis, Angela de. Tumulti: moltitudini ribelli in età moderna. 
Some argue that military violence increased in the period between 1500 and $1700 .{ }^{133}$ We have already had occasion to point out that this is not nowadays a unanimous opinion. In the end, as Francesco Benigno wrote with rotundity and insight, "violence is not a thing, it is a judgment". ${ }^{134}$ However, first the Italian Wars, then the European wars of religion had bathed Western Europe in blood throughout the $16^{\text {th }}$ century. In a context modified by the looming Turkish threat and the unexpected expansion of the ecumene, together with the effect the development of the printing press must have had on the spread and interpretation of all this, the perception of war, in a century that also experienced nuovi e sanguinosi modi di guerreggiare, in Guicciardini's words, ${ }^{135}$ must also have undergone significant changes. The discovery of the inner barbarism, within a broken Christendom, and the blurring of differences with the external barbarian and the new savage humanity were undoubtedly a novelty that has since then left its imprint in one sense or another on European history and the discourses about this. ${ }^{136}$ So too has the central role of war in reflections about how to organise the coexistence of Europeans ${ }^{137}$ -with enormous long-term political consequences.

However, the feud was not replaced directlly by a State monopoly over war. This is not the conclusion that should be reached from the criminalisation of the former and the restriction of the concept of the latter once the ius ad bellum effectively became an exclusive prerogative of the prince and war then became primarily external, war between princes. As shown above, the sole possibility of internal resistance and of this leading to a resort to arms — not to mention tyrannicide-could be considered juridically as a licit option ${ }^{138}$ conditioned, if not belied, the fact that the identification

Bologna: Il Mulino, 2013: 107 and following. For the relation between discursive strategies and political action see also the rich example analysed by Bellabarba, Marco. "Ordine congiunto e ordine stratificato: note su diritto di faida e territorio nel tardo Medioevo", Chiesa cattolica e mondo moderno: scritti in onore di Paolo Prodi, Adriano Prosperi, Pierangelo Schiera, Gabriella Zarri, eds. Bologna: Il Mulino, 2007: $387-$ 401, and more generally, Gamberini, Andrea. "The language of politics and the process of state-building: approaches and interpretations", The Italian Renaissance State, Andrea Gamberini, Isabella Lazzarini eds. Cambridge (UK): Cambridge University Press, 2012: 406-424.

133. Like Reinhardt, Wolfgang. Storia del potere politico in Europa. Bologna: Il Mulino, 2001: 421 and following.

134. Benigno, Francesco. Las palabras del tiempo...: 172.

135. In his Storia d'Italia, but I take the quote from Fournel, Jean-Louis; Zancarini, Jean-Claude. La grammaire de la république: langages de la politique chez Francesco Guicciardini (1483-1540). Genoa: Droz, 2009: 376.

136. Schaub, Jean-Frédéric. “Nous, les barbares: expansion européenne et découverte de la fragilité intérieure", Histoire du monde au XV siècle. 2: Temps et devenirs du monde, Patrick Boucheron, dir. Paris: Fayard, 2012: 672-700; Scuccimarra, Luca. I confini del mondo: storia del cosmopolitismo dall'Antichità al Settecento. Bologna: Il Mulino, 2006: 189 and following.

137. Fournel, Jean-Louis. "Dire autrement la politique et la guerre européennes (XVI ${ }^{\mathrm{e}} \mathrm{XVII}{ }^{\mathrm{e}}$ siècles)", Guerres, conflits, violence: l'état de la recherche, Paris: Autrement, 2010: 32-35; Barbier, Maurice. La modernité politique. Paris: Presses Universitaires de France, 2000: 50-54.

138. Benedictis, Angela de. Politica, governo e istituzioni...: 297 and following; Benedictis, Angela de. "Abattere I tiranni, punire I rebelli: diritto e violenza negli interdetti del Rinascimento". Rechtsgeschichte, 11 (2007): 76-93; Benedictis, Angela de. "Resisting Public Violence: Actions, Law and Emotions", Finding Europe: Discourses on Margins, Communities, Images, Anthony Molho, Diogo Ramada Curto, eds. New York- 
of war with the prince was an authentic monopoly. Regarding external wars, while the Thirty Years War finally managed to ruin all dreams of universal monarchy, ${ }^{139}$ the new international order that arose from the fragile peace treaties of the $1640 \mathrm{~s}$ and 50s does not seem to have brought with it a radical redefinition of the political subjects who were then acting on the European geopolitical stage, however much the "myth of Westphalia" is still recited nowadays as that of the birth of a first modern system of States. ${ }^{140}$ Far from it, it was just around these dates, however, when the twin ideas of a State as a political artifice and an individual as a "person", the two inventions that would bring with them a drastic lurch towards political modernity, were only just beginning to be imagined or suspected, with war certainly present in the historical reality and as a logical trigger. But it would still take almost one and a half centuries, at least on the continent, for the Leviathan to come to life in a painful birth and, by expropriating the old "persons" who had all iurisdictio (all political power), leave them as mere private subjects.

Did war create the State via taxation? For the period under consideration here, we should at least doubt it. ${ }^{141}$ It is not only that the thesis - "an essentially outside-in and above-below explanation" - exudes a large dose of the old Rankean postulate of the primacy of foreign policy and ignores the varied internal social and political dialectic present in each case, as has been argued from a perspective of "political Marxism" that keeps alive the once most appreciated and heeded debate about the transition from feudalism to capitalism. ${ }^{142}$ Nor is it either only a question of the haste that leads some to preach the excessively early consummation of this ménage à trois, as it has been wittily called; ${ }^{143}$ nor that the explicative contrivance made up of these three pieces having a certain air of a mechanism for the natural selection of states with markedly teleological bias, "sometimes of the dangerous teleology

Oxford: Berghahn Books, 2007: 273-290; Benedictis, Angela de. Tumulti...; Jouanna, Arlette. Le devoir de révolte: la noblesse française et la gestation de l'État moderne, 1559-1661. Paris: Fayard, 1989; Turchetti, Mario. Tyrannie et tyrannicide de l'Antiquité à nos jours. Paris: Presses Universitaires de France, 2001.

139. See Rosbach, Franz. Monarchia universalis: storia di un concetto cardine della politica europea (secoli XVIXVIII). Milan: Vita e Pensiero, 1998.

140. From different perspectives, Osiander, Andreas. "Sovereignty, International Relations, and the Westphalian Myth". International Organization, 55 (2001): 251-287; Teschke, Benno. The Myth of 1648: Class, Geopolitics and the Making of Modern International Relations. London: Verso, 2003.

141. As one might also qualify an affirmative response for the contemporary epoch: "warfare is not more than a catalyst of state building but to ignite and sustain fire one needs solid and durable wood", as Siniša Malešević wrote. He believed that that intervention was also essential in the processing of ideological factors that give social cohesion and political legitimacy. See Malešević, Siniša. “Did Wars Make NationStates in the Balkans?: Nationalisms, Wars and States in the $19^{\text {th }}$ and early $20^{\text {th }}$ Century South East Europe". Journal of Historical Sociology, 25/3 (2012): 299-330 the quote is on p. 324.

142. Techke, Benno. "Revisiting the 'War-Makes-States' Thesis: War, Taxation and Social Property Relations in Early Modern Europe", War, the State and International Law in Seventeenth-Century Europe, Olaf Asbach, Peter Schröder, eds. Farnham: Ashgate, 2010: 35-59, a quote between hyphens, on p. 42.

143. Carocci, Sandro; Simone M. Collavini. "The Cost of States: Politics and Exactions in the Christian West (Sixth to Fifteenth Centuries)", Diverging Paths? The Shapes of Power and Institutions in Medieval Christendom and Islam, John Hudson, Ana Rodríguez, eds. Leiden \& Boston: Brill, 2014: 125-158: 148; also Italian translation in Storica, 52 (2012): 7-48: 36. 
aimed at explaining what has made us superior". ${ }^{144}$ These are the typical drawbacks of the history of great strides that historical sociology tends to fall into and that leads to mistaking causes for conditions of possibility. But rather than any of that, what is at stake regarding the difficulty of uncritically accepting that surprisingly successful and widespread tripartite formula is a conceptual problem: ${ }^{145}$ namely, that which underlies the usual (implicit or explicit) likening of prince and State, ${ }^{146}$ an assimilation whose usual outcome is to mistakenly take for granted, for example, what law or legislation must have been at the time, as we saw earlier, or for that matter, also taxation. But even with prerogatives which undoubtedly set him apart as a "mystical body", acknowledged duties and functions, and the convention that he should have the adequate means to fulfil them, in that model of political organisation which has come to be termed jurisdictional (the fundamental model for the architecture of European kingdoms and republics of the $13^{\text {th }}-18^{\text {th }}$ centuries), the prince (whether an individual or a collective person) was not the State but $a$ state (in the sense of status), since in order to become the former and cease to be the latter, it was imperative to change the nature of the legal order.

Why would first the late medieval and then the early modern military competition need a transformation of its main participants in a State-building sense? It was a contingent result, one would say. Then, why organise the story from this result, privileging this point of view? Did England not become a military power in the $18^{\text {th }}$ century, financed with a very heavy taxation policy that was the responsibility, not of the king, but rather Parliament, without that altering substantially a typically jurisdictional institutional system and government? ${ }^{147}$ The evolution of the kingdoms and republics on the continent was surely distinct and varied, and a more pressing and ongoing mutual military pressure must have contributed to this, one that this insular kingdom was freed from. But what decisively marked the difference was undoubtedly the disparate degree of corporative integration reached in each case, which obeyed each one's particular formative history, conditioned the fiscal model and determined the level of territorial and political cohesion. If this forced a resort to informal or, in the literal sense, extraordinary, forms of government with the aim of streamlining the reaching of a target or increasing efficacy in the handling of a question, as was effectively frequently done in relation with military affairs, we know that such expedients found a habitual justification, although not always pacific, in the "economic" and "absolute" dimensions of the power of the

\footnotetext{
144. Carocci, Sandro; Simone M. Collavini. "Il costo degli stati: politica e prelievo...": 7-48: 36.

145. "The broad consensus and widespread unanimity across the disciplines of history, historical sociology and International Relations on the significance of internal nexus between war -or, more broadly, geopolitical competition - taxation and early modern state-formation constitutes", in Benno Teschke's opinion, "an exceptional rarity in the field of human enquiry". See "Revisiting the 'War-Makes-States' Thesis...": 35.

146. For the contrast between the two, Schaub, Jean Fréderic. "Sobre el concepto de Estado". Historia Contemporánea, 28 (2004): 47-51.

147. As the role of jurisprudence of the ius commune corresponded there, as is known, to that of a differentiated common law. About what is said in the text, see Mannori, Luca; Sordi, Bernardo. Storia del diritto amministrativo...: 79 and after, and also for the following.
} 
prince. Thus, it was not something entirely unrelated to an institutional order of a jurisdictional nature. They neither could (for material and cultural reasons which there is no room here to develop) nor claimed to be exponents of a new state logic or rationality, and its use, even where it reached a greater intensity, as happened in France, although it permitted the development of a parallel bureaucracy, this was not presented as an alternative to the old magistratures, and was not configured, ultimately, according to la 'moderna' contrapposizione tra chi giudica e chi amministra. ${ }^{148}$

There were formulas and mechanisms through which the main European political powers prior to the $19^{\text {th }}$ century could maintain an effective and by no means negligible military force without this being accompanied by an unusual bureaucratic deployment, by a redoubled coercive capacity or any other of the assumptions that are usually brought up when the argument is focussed on a perspective of Statebuilding. The resort to "military enterprises", whose flourishing throughout the late medieval and early modern periods has recently been highlighted, was undoubtedly one of these formulas. ${ }^{149}$ And the same historiography that has not managed to rid itself of the State as a concept, as an institutional reality or as a tool for analysing the Ancien Régime, can only increasingly underline in recent decades its weakness, the enormous rift between its rhetoric and the reality of the power it was able to exercise, its dependence on negotiation and agreement with peripheral or local powers. What kind of Leviathan was this? Would it not be better now to accept that this is a mirage and declare its non-existence? If not, there is a real risk of becoming ensnared in its logic, or, in the best of cases, of it hindering the appreciation of another logic that had little or nothing to do with the State.

After fighting against the "feudal revolution" around the year 1000, Dominique Barthélemy declared himself instead a rather convinced "mutationist" in the case of the $12^{\text {th }}$ century, a century, he said, that divided medieval history into two epochs. ${ }^{150}$ The feud and informal justice would have dominated the forms of establishing order in the former period, which would have given way in the mentioned century to a savant law and the "genesis of the modern State". Even the most seasoned historiography of the High Middle Ages ends up declaring evident, in terms of what followed, things it shouldn't. A very recent and detailed reconstruction of the campaign carried out in the region of the Upper Rhine between July 1444 and March 1445 by the future Louis XI of France, at the head of a large army mainly made up of mercenaries, clearly shows, conversely, how the intricate network of the multiple powers with different reach that intertwined, overlapped and competed in the region, the autonomous strategy decided by each of these, the changing and

\footnotetext{
148. "the 'modern' contradistinction between who judges and who administers": Mannori, Luca; Sordi, Bernardo. Storia del diritto amministrativo...: 100-101.

149. Parrott, David. The Business of War: Military Enterprise and Military Revolution in Early Modern Europe. Cambridge (UK): Cambridge University Press, 2012; War, Entrepreneurs, and the State in Europe and the Mediterranean, 1300-1800, Jeff Fynn-Paul, ed. Leiden \& Boston: Brill, 2014.
}

150. Barthélemy, Dominique. "La vengeance, le jugement et le compromis", Le règlement des conflits au Moyen Âge. Actes du XXXI congrès de la SHMESP (Angers, 2000). Paris: Publications de la Sorbonne, 2001: 11-20: 13 . 
crosslinked alliances or the important political role played in this context by the Council of Basel as the arbitration and mediation agency between the contenders, all made up a scenario that can hardly give adequate reason to "the language of nationhood and state-formation". ${ }^{151}$ What the $12^{\text {th }}$ century actually ushered in was a jurisdictional political culture that historians have tended to ignore by considering it as merely the prelude to the state political culture. A whole stage of European history is thereby lost. And it is a shame, because paying it due attention helps us to understand that the advent of the State was not something necessary and inevitable. It was an option, as was at the time, by constitution, a jurisdictional modernity. ${ }^{152}$ But that, as they say, is another story.

\section{Conclusions}

For people's beliefs about a political system are not something outside of it, they are part of it. Those beliefs, however they are formed or determined, do determine the limits and possible development of the system; they determine what people will put up with, and what they will demand. ${ }^{153}$

Two brief, shall we say, methodological observations to finish with. The first is that, despite everything, the above approach remains quite far from the subject it contemplates. Accordingly, the resulting image has the characteristics of aerial photography. At first sight, the details may not be evident. And these are always important; as we know, God is in the detail. But it is only a way to offer an elementary cartography. Two factors work in favour of this being feasible without great distortions, despite the breadth of the territory covered: that this territory can be captured quite truthfully with one lens, which provides the ius commune, and that the differences in the details, however significant they are when seen from closer up, do not cancel out the similarities, the common forms that were expressions, as Watts stated, of "the consonances and shared patterns - the structures - of European political life". ${ }^{154}$

The second observation is as follows. For a long time, if not always, history as a discipline has been obsessed with its scientific status, which, especially in the decades after the Second World War, led it to flirt openly with the so-called social sciences to the detriment of its traditional prolonged courtship with philology. There is no lack of voices among those who nowadays practice the best version (and the

151. Hardy, Duncan. "The 1444-5 expedition of the Dauphin Louis to the Upper Rhine in geopolitical perspective". Journal of Medieval History, 38/3 (2012): 358-387.

152. Portillo, José María. “La constitución en el Atlántico hispano, 1808-1824". Fundamentos: cuadernos monográficos de teoría del estado, derecho público e historia constitucional, 6 (2010): 123-178.

153. Macpherson, Crowford Brough. The Life and Times of Liberal Democracy. Oxford: Oxford University Press, 1977: 6 .

154. Watts, John. The Making of Polities...: 3. 
most modest, it must be said) of social science available who suggest, however, that it should perhaps rather be the social scientists who should take note of history, in other words, of the practice of the good historians. ${ }^{155}$ One could say - for we cannot go into details here either - that the difficulty that underlies one attitude or the other is the same: that of adapting the tools to the problems, a difficulty that first appeared in the early $19^{\text {th }}$ century and whose most famous episode was the Methodenstreit towards the end of the same century. ${ }^{156}$ However, nowadays, we know how little founded a radical contrast between understanding and explanation was, ${ }^{157}$ two operations that can indeed work, and in fact do work, as distinct phases of a single process designed to explain a given social reality. If individual or collective beliefs are not alien to the explanation of actions, in the strong sense that they are liable to form part of their immediate causes, understanding the beliefs of people from the past, of their own perception of things, cannot be the private reserve of a separate history, of historiographic speciality. In those beliefs are also cast the institutions that regiment social life and are used by those who participate in it according to their interests and preferences. In his introduction to Democracy in America, de Tocqueville wrote that "a new science of politics is needed for a new world"158. The old civilis sapientia was of no use for understanding a new reality, in the same way that some of our most common political concepts are of little use for us, children of this new world, to understand that old one that no longer exists. They are pregnant with meaning; ${ }^{159}$ or require cumbersome redefinitions that end up being seen as less than fruitful. ${ }^{160}$ To tackle the political history that preceded the present time, and as war is the motive that has brought us here, it would be worth taking into account something similar to what John France recently stated about military history: "Looking at the past through technological glasses is a distortion [...]. The sophisticated analytic terms used by armies nowadays are very modern and applying them to distant events is misleading". ${ }^{161}$

155. Elster, Jon. "One social science or many?". 2010 World Social Science Report Knowledge Divides (2010). United Nations Educational, Scientific and Cultural Organisation-International Social Sciencia Council. 11 septiembre 2013. <http://unesdoc.unesco.org/images/0019/001906/190655e.pdf>.

156. Ovejero, Félix. El compromiso del método: en el origen de la teoría social posmoderna. Barcelona: Montesinos, 2003: 39 and following.

157. Boudon, Raymond. Metodologia della ricerca sociológica. Bologna: Il Mulino, 1996: 19 and following. 158. Tocqueville, Alexis da. Democracy in America. New York: Vintage Books, 1945: 1, 7.

159. Hespanha, António Manuel. "Le débat autour de l'État moderne". Adhésion et résistances à l'État en France et en Espagne, 1620-1660, Anne-Marie Cocula, ed. Bordeaux: Presses Universitaires de Bordeaux, 2001: 11-21; Schaub, Jean-Frédéric. "La notion d'État moderne est-elle utile?". Cahiers du monde russe, 46/1-2 (2005): 51-64.

160. Lyon, Jonathan R. "The Medieval German State in Recent Historiography". German History, 28/1 (2010): 85-94.

161. France, John. Perilous Glory...: 13. 